\title{
Targeting MCL-1 in cancer: current status and perspectives
}

\author{
Haolan Wang ${ }^{1}$, Ming Guo ${ }^{1}$, Hudie We $\mathrm{i}^{1^{*}}$ and Yongheng Chen ${ }^{1,2^{*}}$ (])
}

\begin{abstract}
Myeloid leukemia 1 (MCL-1) is an antiapoptotic protein of the $B C L-2$ family that prevents apoptosis by binding to the pro-apoptotic BCL-2 proteins. Overexpression of $\mathrm{MCL}-1$ is frequently observed in many tumor types and is closely associated with tumorigenesis, poor prognosis and drug resistance. The central role of $\mathrm{MCL}-1$ in regulating the mitochondrial apoptotic pathway makes it an attractive target for cancer therapy. Significant progress has been made with regard to MCL-1 inhibitors, some of which have entered clinical trials. Here, we discuss the mechanism by which MCL-1 regulates cancer cell apoptosis and review the progress related to MCL-1 small molecule inhibitors and their role in cancer therapy.
\end{abstract}

Keywords: MCL-1, BCL-2 family, Cancer, Apoptosis, Inhibitor

\section{Introduction}

The orderly and delicate regulation of apoptosis of cells under physiological and pathological conditions is an autonomous clearance mechanism adopted by cells to maintain their own homeostasis [1]. Under normal circumstances, cell growth, proliferation and death maintain a dynamic balance to ensure cellular homeostasis and normal physiological function. When an organism is subjected to certain stimuli that disrupt this balance, it may cause cell proliferation to outpace apoptosis, potentially even leading to tumorigenesis.

There are two apoptotic pathways: the intrinsic (or mitochondrial) pathway of apoptosis and the extrinsic pathway of apoptosis. The mitochondrial pathway is activated by intracellular signals and is strictly controlled by the BCL-2 family [2]. BCL-2 family proteins share one or four BCL-2 homologous domains (BH 1-4) and are grouped into three subsets (Fig. 1a) [3, 4]: antiapoptotic

\footnotetext{
*Correspondence: hudiewei18@163.com; yonghenc@163.com ${ }^{1}$ Department of Oncology, NHC Key Laboratory of Cancer Proteomics, Laboratory of Structural Biology, National Clinical Research Center for Geriatric Disorders, Xiangya Hospital, Central South University, Changsha 410008, Hunan, China

Full list of author information is available at the end of the article
}

BCL-2 proteins (BCL-2, BCL-xL, BCL-W, MCL-1 and BCL-2-related gene $\mathrm{A} 1$ ), proapoptotic effectors (BAX and $\mathrm{BAK}$ ) and $\mathrm{BH} 3$-only proteins. The $\mathrm{BH} 3$-only proteins are subdivided into the "activator" (BIM, BID and PUMA) and the "sensitizer" (BAD, BIK, BMF, HRK and NOXA) [5]. These BCL-2 family proteins function through complex interactions to regulate the integrity of the mitochondrial membrane (Fig. 1b).

Myeloid leukemia 1 (MCL-1) is an antiapoptotic member of the BCL-2 family. MCL-1 inhibits mitochondrial outer membrane permeabilization (MOMP) and the release of cytochrome $\mathrm{C}$ from mitochondria. MCL-1 is necessary for the survival of many cells, such as the nervous system [6], T/B lymphocytes [7], and cardiomyocytes [8]. MCL-1 also has high oncogenic potential and is upregulated in a range of malignancies, including solid tumors and hematological malignancies [9]. Overexpression of the MCL-1 protein or amplification of the MCL-1 gene protects cancer cells from apoptosis and decreases their sensitivity to commonly used anticancer drugs, which has emerged as a resistance mechanism against multiple anticancer therapies, including radiotherapy, chemotherapy, and $\mathrm{BH} 3$ mimics targeting $\mathrm{BCL}-2 / \mathrm{BCL}-$ $\mathrm{XL}[10,11]$. Therefore, MCL-1 is a very promising target for tumor treatment. original author(s) and the source, provide a link to the Creative Commons licence, and indicate if changes were made. The images or other third party material in this article are included in the article's Creative Commons licence, unless indicated otherwise in a credit line to the material. If material is not included in the article's Creative Commons licence and your intended use is not permitted by statutory regulation or exceeds the permitted use, you will need to obtain permission directly from the copyright holder. To view a copy of this licence, visit http://creativecommons.org/licenses/by/4.0/. The Creative Commons Public Domain Dedication waiver (http://creativeco mmons.org/publicdomain/zero/1.0/) applies to the data made available in this article, unless otherwise stated in a credit line to the data. 


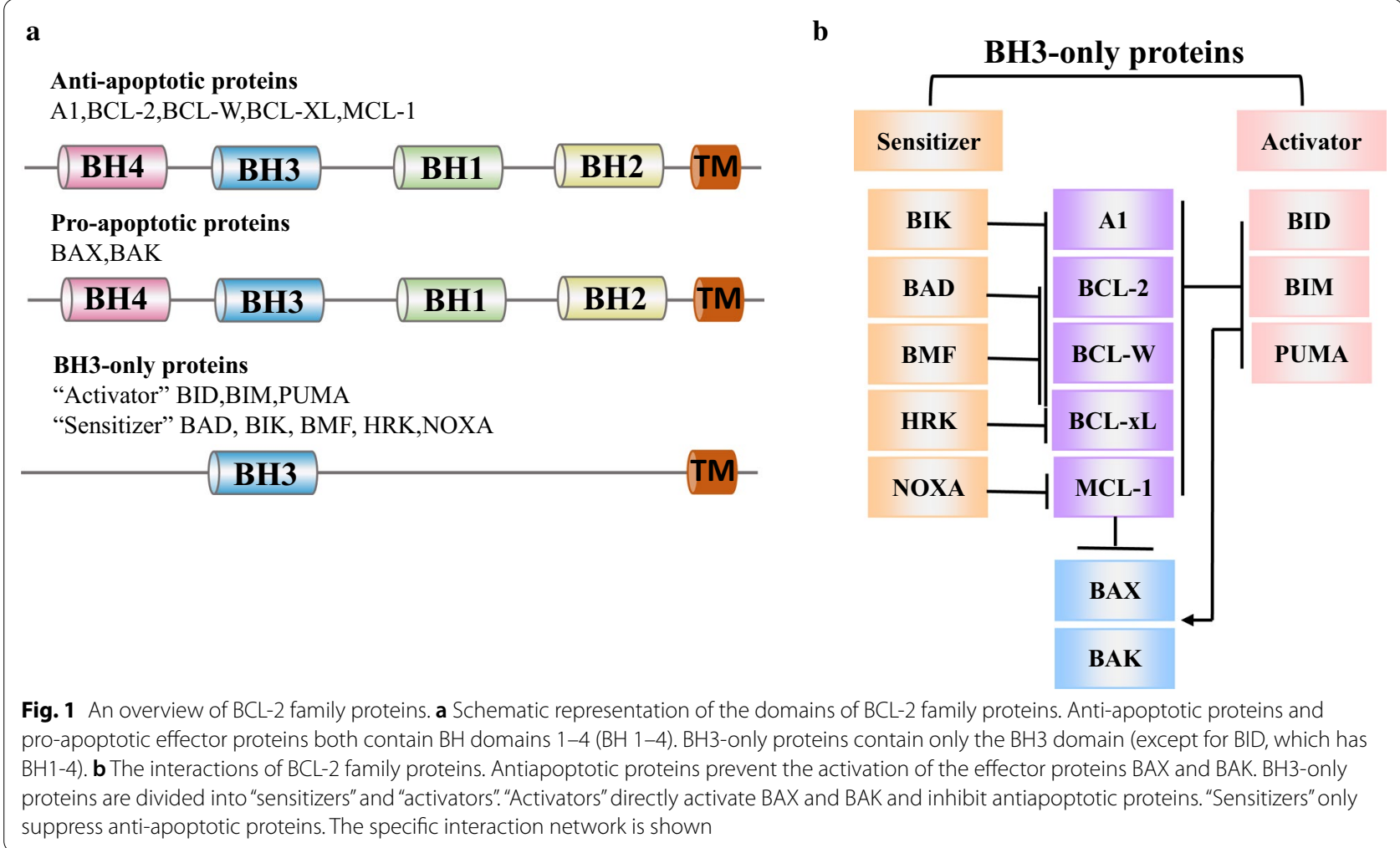

In this review, we describe the known functions of MCL-1 in normal and malignant cells and discuss the development and clinical trials of some MCL-1 small molecule inhibitors in the quest for new anticancer drugs.

\section{Isoforms of MCL-1 protein}

There are three splicing variants of the human MCL-1 gene, including MCL-1L, MCL-1S and MCL-1ES (Fig. 2a). The three splice variants play distinct roles in apoptosis. The long variant (MCL-1L) encoded by exons I to III of the MCL-1 gene acts as an anti-apoptotic factor, and MCL-1L is traditionally referred to as MCL1. MCL-1 shares four $\mathrm{BH}$ domains. Similar to other multidomain $\mathrm{BCL}-2$ proteins, the tertiary structure of the $\mathrm{BH}$ core of MCL- 1 is composed of eight $\alpha$ helices (Fig. 2b). The BH1 domain constitutes turn regions linking helices 4 and 5 , and the $\mathrm{BH} 2$ domains constitute turn regions linking helices 7 and 8 . The $\mathrm{BH} 3$ domain is located in helix 2 , and the $\mathrm{BH} 4$ domain is located in helix 1 . Helices $2-5$ and 8 constitute a hydrophobic groove (called the $\mathrm{BH} 3$-binding groove) that is critical for its interactions with the $\mathrm{BH} 3$ domain of proapoptotic BCL-2 members (Fig. 2c, d) [12]. MCL-1 also has a transmembrane $\alpha$-helix domain at the $\mathrm{C}$-terminus, allowing it to localize to the cell membrane, especially the outer mitochondrial membrane [13]. In particular, MCL-1 has a large N-terminal region with a PEST domain rich in proline $(\mathrm{P})$, glutamic acid $(\mathrm{E})$, serine $(\mathrm{S})$, and threonine $(\mathrm{T})$. Multiple sites of phosphorylation, ubiquitination, and caspase enzymatic cleavage are present within the PEST domain, allowing for rapid fine-tuning of the function and stability of the MCL-1 protein in response to environmental and stress signals, consistent with the short half-life of the MCL-1 protein [13].

The two short isoforms, MCL-1S and MCL-1ES, display proapoptotic activity [14]. MCL-1S has only a BH3 domain, which represents a new pro-apoptotic BH3only protein and is primarily located in the cytoplasm. Dimerization of MCL-1S and MCL-1L can antagonize the antiapoptotic effect of MCL-1L [15]. The splice variant MCL-1ES retains the $\mathrm{BH} 3, \mathrm{BH} 1$, and $\mathrm{BH} 2$ domains. It can induce mitochondrial apoptosis independently of BAK and BAX. MCL-1L can facilitate the proper localization of MCL-1ES oligomers on the mitochondrial outer membrane, and MCL-1ES neutralize the antiapoptotic activity of MCL-1L. These findings indicate that MCL-1ES may be a selective and effective target of MCL-1L in diseases that involve abnormal MCL-1L expression $[16,17]$ 
$\mathbf{a}$ MCL-1L $\quad$ PEST BH3-BH1 BH2-TM MCL-1S PEST BH3 MCL-1ES BH3- BH1 BH2-TM

b

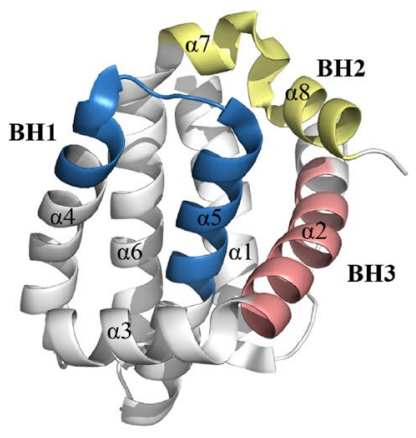

Apo MCL-1(6QB3) c

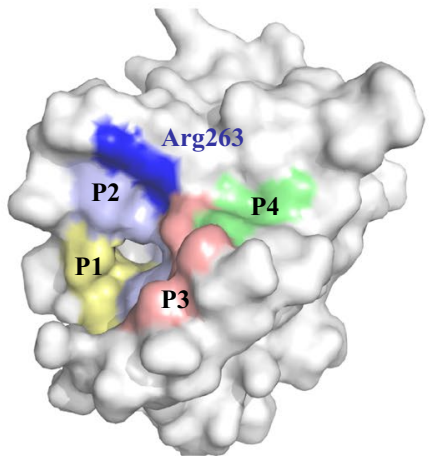

MCL-1(2NL9) d

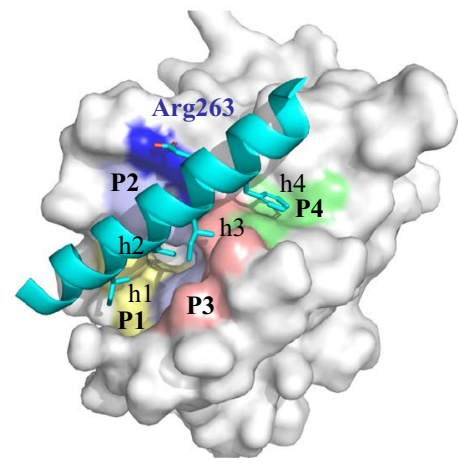

MCL-1· BIM(2NL9)

Fig. 2 The isoforms and three-dimensional structure of $M C L-1$. a Three splicing variants of the human $M C L-1$ gene. $\mathbf{b}$ Cartoon representation of the tertiary structure of MCL-1 (PDB ID: 6QB3). The BH core of MCL-1 is composed of eight a helices. The BH1 (blue), BH2 (yellow) and BH3 (red) domains form a hydrophobic groove called the BH3-binding groove. c Surface representation of the BH3 binding groove of MCL-1 (PDB ID: 2NL9). The four hydrophobic pockets (P1-4) are highlighted and labelled. $\mathbf{d}$ Structure of the MCL-1/BIM complex (PDB ID: 2NL9). MCL-1 is shown as surface. BIM is shown as cyan cartoon. The four hydrophobic residues of BIM (h1, h2, h3, h4) are shown as cyan sticks

\section{Regulation of MCL-1 expression}

MCL-1 is subject to multiple modulations at the transcriptional, translational, and posttranslational levels. Many studies have suggested that multiple cytokines and signaling pathways are involved in the regulation of MCL-1. VEGF and interleukin-6 (IL-6) can regulate the expression of MCL-1 via autocrine signaling loops [18]. Activation of the ERK survival pathway prevents MCL-1 degradation and enhances its stability [19]. Activation of the Notch-1 signaling pathway induces the production of IL-6, further promoting the expression of MCL-1 [20]. MCL-1 protein levels are also regulated by cytokines, including IL-15 and IL-22, through the STAT3/MCL-1 [21] pathway or JAK/STAT and PI3K pathways [22].

Broad networks of miRNAs can regulate the expression of MCL-1. MiR-596 negatively regulates the MAPK/ERK signaling pathway by targeting MEK1 and regulates the apoptosis pathway by targeting MCL-1 and BCL-2 [23]. Upregulation of miR-15a/miR-16-1 leads to downregulation of the target genes BCL-2, MCL-1 and cyclin-D1, which directly leads to the death of leukemia cells [24,
25]. Other miRNAs, such as miR-26a [26], miR-15a, miR101 and miR-197, can downregulate the expression of MCL-1 in vivo and inhibit cancer cell growth or apoptosis [27].

Stability of the MCL-1 protein can be controlled by a variety of E3 ubiquitin ligases, including MULE, SCFFbw7, APC/CCdc20 and SCFB-TrCP. These ubiquitin ligases effectively polyubiquitinate MCL-1 for degradation, while the deubiquitinases USP9X [28] and USP13 [29] stabilize expression of the MCL-1 protein. The PEST domain of MCL-1 contains many phosphorylation sites, such as Thr-92, Thr-163, Ser-64, Ser-155 and Ser-159. Phosphorylation of MCL-1 residues in the PEST domain by protein kinases, such as CDK1/2, GSK-3, JNK, and ERK, also affects the stability of MCL-1 [13, 30, 31].

\section{MCL-1 as a target for cancer therapy}

MCL-1 is a key survival factor for many cell types, allowing it to strictly regulate cell fate. In normal cells, MCL-1 sequesters the BH3-only activators BIM, BID and PUMA or neutralizes the effector proteins BAX and BAK, 
thereby antagonizing apoptosis [32] (Fig. 3a). When cells experience irreparable damage, they initiate an apoptotic program that increases the expression of pro-apoptotic BH3-only proteins, such as BIM, PUMA and NOXA $[33,34]$. Then, BAX and BAK homopolymerize to form pores in the outer mitochondrial membrane, leading to infiltration of cytochrome $\mathrm{c}$ and other apoptotic proteins into the cytoplasm, promoting the formation of apoptotic microsomes, activation of caspases, cell lysis, and death $[35,36]$.

In recent years, many studies have shown that MCL-1 is essential for the survival and development of cancer cells. High levels of MCL-1 have been reported in hematological malignancies and a wide range of solid tumors [37, 38]. Overexpression of MCL-1 in cancer cells disrupts the balance between antiapoptotic and proapoptotic proteins, which prevents cancer cells from undergoing apoptosis, resulting in malignant proliferation [39] (Fig. 3b). Cancer has the capacity to develop multi-drug resistance against various therapies of different molecular pathways [40]. The mechanisms of resistance can be divided into intrinsic and acquired resistance. To escape apoptosis, cancer cells often express high levels of anti-apoptotic proteins and are "attracted" to them for their survival. Inhibition of one member of the BCL-2 anti-apoptotic family may cause dysregulation of the expression of other members. Increased expression of MCL-1 is a common response to long-term treatment with selective inhibitors of BCL-2/BCL-XL [41].Therefore, available evidences

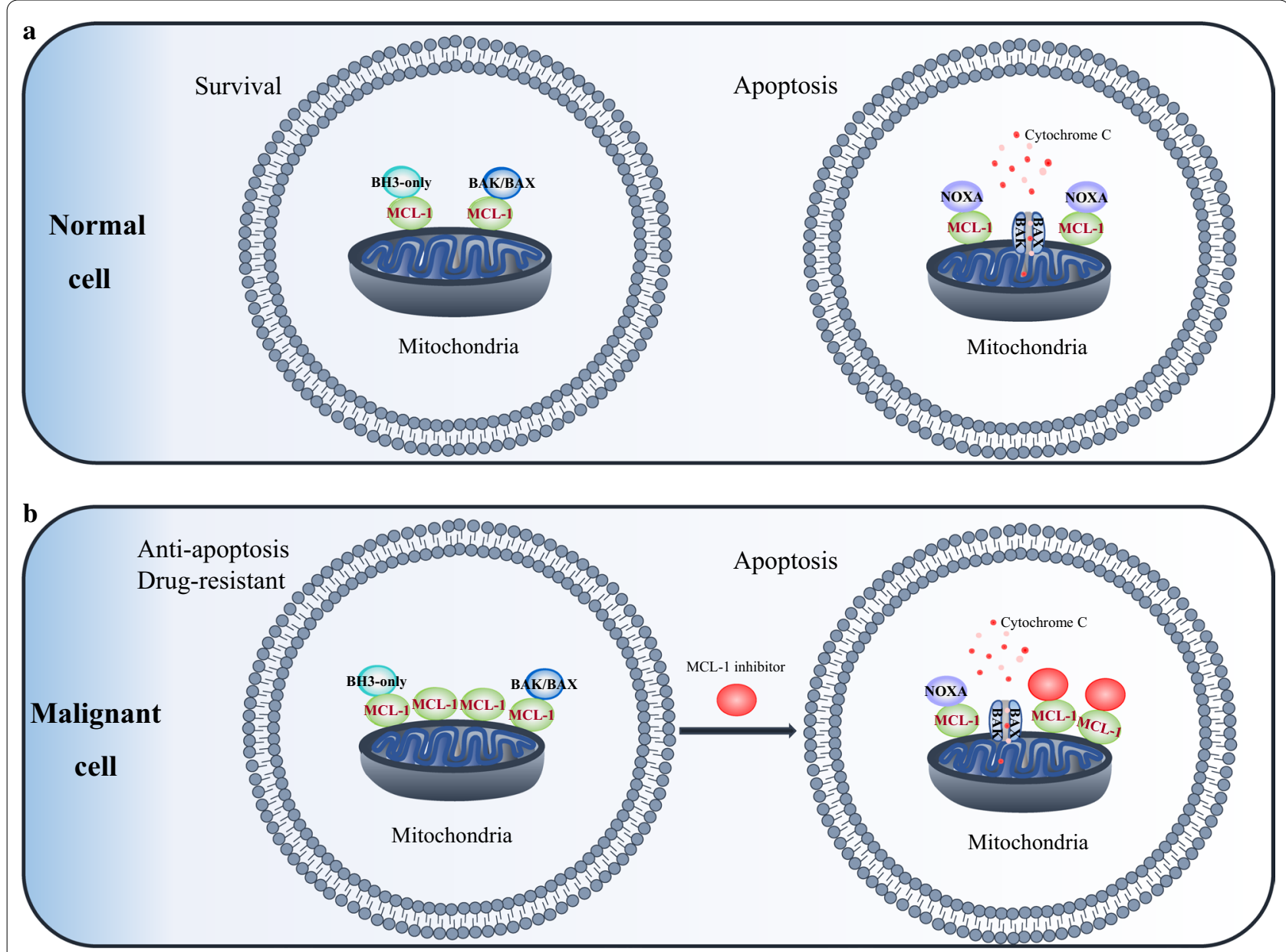

Fig. $3 \mathrm{MCL}-1$ as a target for cancer therapy. a In normal cells, MCL-1 sequesters BH3-only proteins or neutralizes the effector proteins BAX and BAK, preventing cell death and maintaining cell survival. Various cell stress factors increase the expression of the special "activator" NOXA, subsequently replacing or preventing MCL-1 binding to BAX and BAK. BAX and BAK homo-oligomerize and form pores spanning the outer mitochondrial membrane to allow cytochrome $C$ to be released into the cytoplasm, which triggers the activation of the caspase cascade and ultimately leads to cell apoptosis. $\mathbf{b}$ In malignant cells, overexpression of MCL-1 allows cancer cells to evade apoptosis by sequestering pro-apoptotic proteins. MCL-1 inhibitors selectively bind to MCL-1, freeing pro-apoptotic proteins, BAX/BAK, which initiates apoptosis 
indicate that MCL-1 is an attractive target for cancer treatment.

\section{Strategies for the discovery of MCL-1 inhibitors}

Many approaches have led to the development of MCL-1 inhibitors. Some drugs were not designed to specifically target MCL-1, but downregulate the expression of MCL-1 in an indirect way. For examples, cyclin-dependent kinase (CDK) inhibitors lead to decreased transcription of MCL-1, mTOR inhibitors block translation of MCL-1, and deubiquitinase inhibitors induce MCL-1 degradation through the proteasome system [42-44]. Here we mainly report strategies for the direct and selective inhibitors against MCL-1.

The realization that $\mathrm{BH} 3$-only proteins function as natural inhibitors of antiapoptotic BCL-2 proteins led to the development of $\mathrm{BH} 3$ mimetics. These $\mathrm{BH} 3$ mimetics bind competitively to the hydrophobic $\mathrm{BH} 3$-binding groove of antiapoptotic proteins, resulting in dissociation of proapoptotic BH3-only proteins or BAX/BAK and subsequent activation of apoptosis. Progress related to $\mathrm{BH} 3$ mimetics targeting BCL-2 and BCL-xL has been made [45], such as ABT-737, which binds BCL-2, BCL-xL, and BCL-W [46]; ABT-263 (navitoclax), which binds BCL-2, BCL-xL [47], and venetoclax (ABT-199), which selectively binds BCL-2 [48] and has been approved by the FDA for chronic lymphocytic leukemia (CLL) treatment.

However, most BCL-2 family inhibitors cannot bind to highly differentiated MCL-1 molecules. Upregulation of MCL-1 has been shown by several studies to be a major limiting factor in the development of ABT-737 and ABT263 resistance in tumor treatment. The creation of highaffinity inhibitors that directly target MCL-1 remains a challenge. Furthermore, MCL-1 has a BH3-binding groove that lacks plasticity. The binding pockets on MCL-1 are shallow and relatively inflexible compared to those of BCL-2 and BCL-xL. Increasing structural studies demonstrate that MCL-1 interact with the BH3-only proteins through a canonical mechanism similar to that of BCL-2 and BCL-xL, in which four hydrophobic residues (h1, h2, h3, and h4) of the BH3 helix of BH3-only proteins respectively interact with four pockets (P1-P4) in the hydrophobic binding groove of MCL-1 (Fig. 2c, d), and a common salt bridge is formed between an Asp of BH3-only proteins and Arg263 of MCL-1[12, 49]. The P1-P4 pockets and Arg263 are considered as hot-spots of MCL-1 to design BH3 mimetics [50].

Although there are many challenges in the process of new drug research and development, the most fundamental is the discovery and optimization of lead compounds [51, 52]. High-throughput screening (HTS) and virtual screening are widely used for the discovery of lead compounds [53, 54]. Molecular modeling can predict the binding mode of small molecules to target proteins, which may facilitate the optimization of small molecule drugs and the development of MCL-1 inhibitors with higher safety and efficacy [53, 54]. In recent years, more strategies have been applied to the screening and optimization of MCL-1 inhibitors, such as NMR-based fragment screening, computational modeling and fragment-based design.

In the following sections, we summarize the current discoveries of direct and selective inhibitors of MCL-1, including the current status and future applications of these small molecule inhibitors, as well as their use alone and in combination to treat a variety of cancers.

\section{Direct and selective inhibitors targeting MCL-1 MCL-1 inhibitors in clinical trials}

In recent years, considerable progresses has been made with potent and highly selective MCL-1 inhibitors. Until now, six compounds have entered phase 1 clinical trials and they have been shown to induce cancer cell apoptosis in preclinical trials (Table 1 ).

\section{$\mathrm{S} 63845 / \mathrm{S} 64315$}

S63845 is a potent and selective small molecule inhibitor of MCL-1 discovered by NMR-based fragment screening. It inhibits MCL-1 with a $K_{i}<1.2 \mathrm{nM}$ and $K d$ of $0.19 \mathrm{nM}$ and has no evident binding to BCL-2 or BCL$\mathrm{xL}\left(K_{i}>10,000 \mathrm{nM}\right)$ [55]. The structure of $\mathrm{S} 63845$ in complex with MCL-1 (PDB: 5LOF) shows that $\mathrm{S} 63845$ forms a salt bridge with $\operatorname{Arg} 263$ via a carboxyl group, while its aromatic scaffold stretches deep into the P2 pocket and a terminal trifluoromethyl group extends into the small $\mathrm{P} 4$ pocket, with some P1 residues constituting part of the P2 pocket (Fig. 4a) [55].

S64315 (MIK665) belongs to the same series of compounds as S63845 [56]. The filling of the P2 pocket and the extension of the $\mathrm{P} 4$ pocket increased the activity of S64315 (PDB: 6YBL) compared to S63845 (Fig. 4b) [57]. S64315 is currently in a phase 1 clinical trial to evaluate the maximal tolerated dose and the recommended dose for expansion. A further study will evaluate the tolerability, safety, and antitumor activity of MIK665 for the treatment of refractory or recurrent lymphoma and multiple myeloma (MM) (NCT02992483) [58], acute myeloid leukemia (AML), and myelodysplastic syndrome (MDS) (NCT02979366) [59]. A dose-escalation study of S64315 in combination with venetoclax for AML is also underway (NCT03672695) [60].

\section{AZD5991}

AZD5991 is a macrocyclic molecular inhibitor with high selectivity and affinity for MCL- $1\left(K_{i}=200 \mathrm{pM}\right.$, $\mathrm{IC}_{50}=0.72 \mathrm{nM}$ ) [61]. AstraZeneca researchers designed 
Table $1 \mathrm{MCL}-1$ targeted anti-tumor drugs in clinical trials

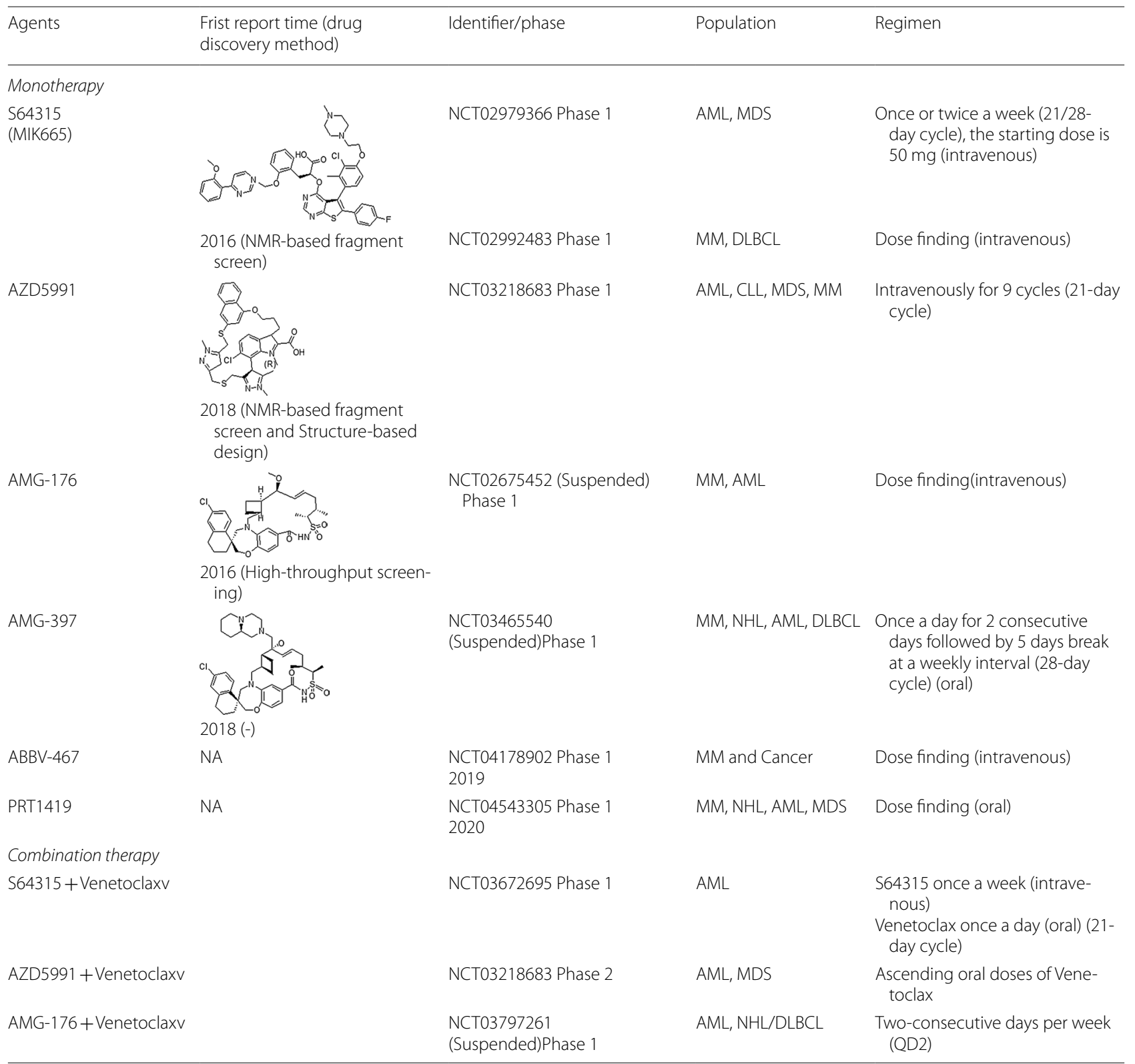

RS Richter syndrome, SLL Small lymphocytic lymphoma

and synthesized AZD5991 by analyzing indole-2-carboxylic acid derivatives previously reported by the Abbvie [62] and Fesik's laboratory [63]. The co-crystal structure (PDB: 6FS0) shows that AZD5991 binds largely in the P2 and P3 pockets (Fig. 4c) [61]. Its naphthalene ring penetrates deep into the P2 pocket, and the indole core interacts mainly with P3 residues. The methyl group distal to the indole core makes contact with $\mathrm{P} 1$ pocket. Moreover, the carboxylic acid orthogonal to the indole ring makes strong salt-bridge interactions with Arg263 [61]. Currently, clinical trials of single-drug intravenous injection of AZD5991 and in combination with venetoclax are ongoing in patients with recurrent or refractory hematologic malignancies (NCT03218683) [64].

\section{AMG-176}

AMGEN screened compound 1 from 248,090 compounds using HTS method, and subsequently optimized to obtain AMG-176 using structure-based design. AMG-176 is a potent MCL- 1 inhibitor $\left(K_{i}=0.06 \mathrm{nM}\right)$ and shows little affinity for BCL-2 $\left(K_{i}=0.95 \mu \mathrm{M}\right)$ and BCL-xL $\left(K_{i}=0.7 \mu \mathrm{M}\right)$ [65]. The structure of MCL-1 


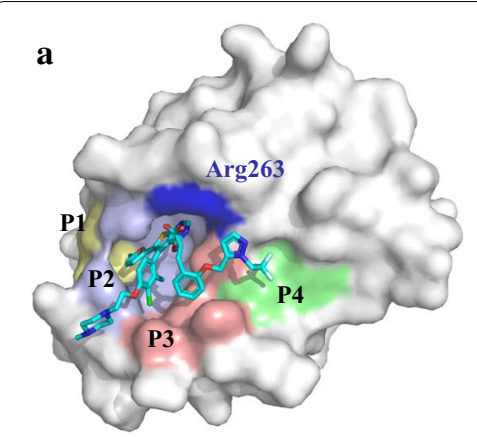

MCL-1·S63845(5LOF)

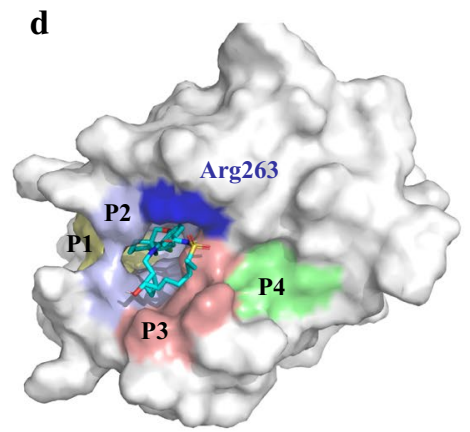

MCL-1· AM-8621 (6OQB)

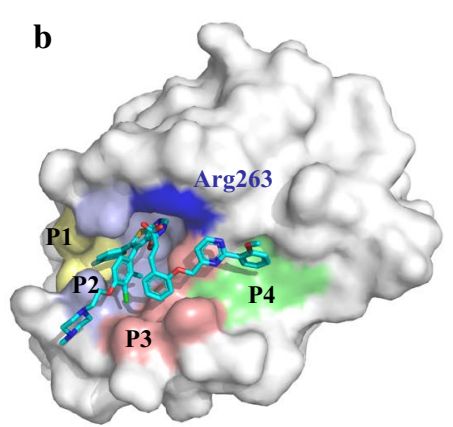

MCL-1·S64315(6YBL)

e

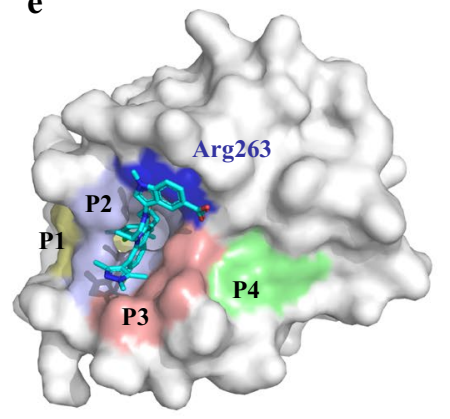

MCL-1 · VU661013(6NE5)

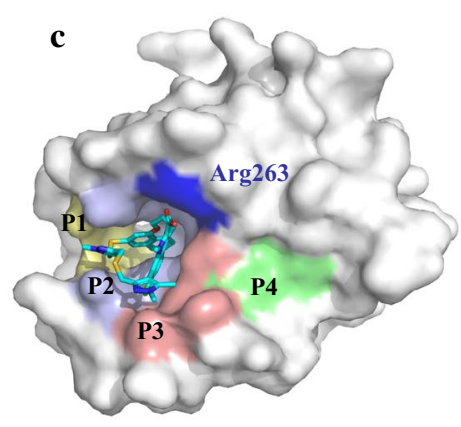

MCL-1· AZD5991(6FS0)

f

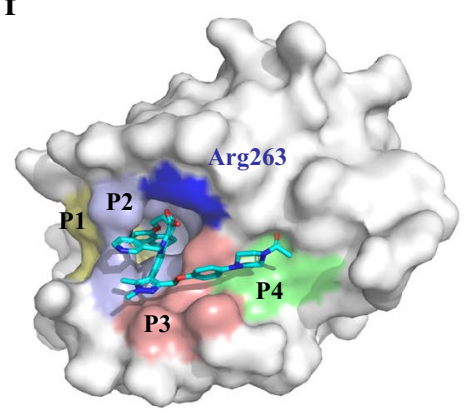

MCL-1 · A-1210477 lead compound(5VKC)

\begin{tabular}{|c|c|c|c|c|c|c|}
\hline \multirow[b]{2}{*}{ MCL-1 } & P1 & \multicolumn{2}{|c|}{ P2 } & P3 & P4 & \\
\hline & $\begin{array}{l}\text { Leu235 } \\
\text { Leu246 } \\
\text { Val249 }\end{array}$ & $\begin{array}{l}\text { Met231 } \\
\text { Val253 } \\
\text { Phe254 } \\
\text { Leu267 } \\
\text { Phe270 }\end{array}$ & $\begin{array}{c}\text { Met250 } \\
\text { Gly271 } \\
\text { Val274 } \\
\text { Leu290 } \\
\text { Ile294 }\end{array}$ & $\begin{array}{l}\text { His224 } \\
\text { Ala227 } \\
\text { Phe228 } \\
\text { Thr266 }\end{array}$ & $\begin{array}{l}\text { Val216 } \\
\text { Val220 } \\
\text { Val265 }\end{array}$ & Arg263 \\
\hline BIM & Ile58 & & & Ile 65 & Phe69 & Asp67 \\
\hline
\end{tabular}

Fig. 4 Co-crystal structures of MCL-1 in complex with its inhibitor. a MCL-1/S63845 complex (PDB: 5LOF), b MCL-1/S64315 complex (PDB: 6YBL), c MCL-1/AZD5991 complex (PDB: 6FS0), D. MCL-1/AM-8621 complex (PDB: 6OQB), e MCL-1/NU661013 complex (PDB: 6NE5), f MCL-1/A-1210477 lead compound complex (PDB: 5VKC). The four hydrophobic pockets (P1-4) and Arg263 are highlighted and labelled. g MCL-1 hot-spots residues for P1-P4 pockets and the four hydrophobic residues of BIM (h1, h2, h3, h4) based on the MCL-1/BIM structure (PDB: 2NL9)

complexed with AM-8621 (PDB: 6OQB), a ligand structurally similar to AMG-176, shows that the inhibitor primarily makes contact with P2 and P3 pockets, whereas no hydrogen bond or salt bridge is observed between the carbonyl group and Arg263 (Fig. 4d) [65]. Recent reports $[66,67]$ show that additional hydrogen bond between the carbonyl group of AMG-176 and Arg263 of MCL-1 would allow for tighter interactions in the P3 pocket. AMG-176 was first subjected to relapsed or refractory MM or AML in a human clinical trial to obtain an intravenous dose of AMG-176 that is safe and tolerable for the patient (NCT02675452) [68]. Another clinical trial of AMG-176 combined with venetoclax is also currently underway [69].

\section{AMG-397}

Based on the chemical structure of AMG-176, a structure-guided approach in combination with ligandbased design was used to obtain AMG-397 with higher affinity and antitumor activity $[66,67]$. AMG-397 is the first oral MCL-1 inhibitor to reached the clinical trial stage. It inhibits MCL-1 with a $K_{i}$ of $15 \mathrm{pM}$ and interferes with the interaction of MCL-1 with BIM in cells [66]. A clinical trial is evaluating AMG-397 in patients with MM, AML, and non-Hodgkin's lymphoma (NHL). AMG-397 was administered orally two days a week, followed by a five-day break. However, due to safety signals of cardiotoxicity, a phase 1 dose escalation clinical trial is being put on hold (NCT 03465540) [70]. Based 
on this safety issue, the first phase of the AMG-176 trial has also been voluntarily suspended.

\section{ABBV-467}

ABBV-467 is a selective MCL-1 inhibitor. Currently, there are few reports on ABBV-467, but it is being studied in a phase 1 clinical study (NCT04178902) [71]. This study will evaluate the safety and tolerability of ABBV467 in adult participants with relapsed/refractory MM.

\section{PRT1419}

PRT1419 is a potent, selective oral inhibitor of MCL-1 developed by Prelude Therapeutics. Prelude Therapeutics claims that PRT1419 specifically binds MCL-1 in preclinical models of hematologic tumors and shows efficacy. Phase I dose expansion study of PRT1419 in relapsed/ refractory hematologic malignancies currently underway (NCT04543305) [72].

\section{Preclinical MCL-1 inhibitors}

Currently, although a small number of MCL-1 inhibitors have entered clinical trials, no drugs have been approved for clinical use. Given the prominence of MCL-1 inhibitors in cancer therapy, researchers have utilized various approaches to identify a cohort of MCL-1 inhibitors (Table 2), which are expected to enter clinical trials.

\section{NOXA-like compound}

NOXA is a naturally occurring, highly selective MCL-1 inhibitor [73]. NOXA can competitively bind MCL-1 and release BAX and BAK, which originally bind to MCL-1. NOXA has been reported to enhance MOMP and apoptosis in a variety of cancers, such as glioblastoma [74], cholangiocarcinoma [75], and chronic myeloid leukemia [76]. Hedir and colleagues identified a compound12 with polar substituents that can bind to the inside of the MCL-1 pocket in a NOXA-like manner, thereby releasing $\mathrm{BIM}$ and BAK and inducing cell apoptosis [77, 78].

\section{BIM-BH3 peptide}

The BH3 domain of BIM can bind to the BH3 hydrophobic groove of BCL-2 antiapoptotic proteins and directly activate the apoptotic effector proteins BAK and BAX. BIM-SAHB ${ }_{\mathrm{A}}$ is a hydrocarbon-stapled peptide based on the $\mathrm{BH} 3$ structural domain of BIM, and its primary intracellular target is MCL-1 [79]. MCL-1 knockout mouse embryonic fibroblasts are resistant to apoptosis induced by BIM-SAHB A the mitochondrial level. Screening of the yeast surface display library of the BIM-BH3 identified the MCL-1-specific peptide MS1 [80]. MS1 induces apoptosis in a variety of MCL-1-dependent tumor cells with higher sensitivity than NoxaA [80].

\section{MIM1, ML311/EU-5346 and UMI-77}

MIM1 was obtained from 71,296 compounds by HTS with the help of fluorescence polarization assay [81]. ML311/EU-5346 was confirmed from 315,100 compounds by HTS, which interfered with the MCL-1/BIM interaction and induced cell death in MCL-1-dependent cell lines $\left(\mathrm{EC}_{50}=0.3 \mu \mathrm{M}\right)[82,83]$. Fardokht et al. identified and verified UMI-59 from 53,000 compounds by HTS method [84]. UMI-77 is the product of further chemical modification of UMI-59 and has a higher affinity for MCL-1, with $K_{i}=0.49 \mu \mathrm{M}$ [84]. These inhibitors were predicted to bind at the P2 and P3 pockets, while forms a hydrogen bond with Arg263 [81, 84].

\section{A-1210477}

Abbvie identified indole acid derivative that selectively bind MCL-1 by HTS method combined with fluorescence polarization assay, which were later optimized to yield A-1210477 [62]. A-1210477 has a potent affinity for MCL-1 $\left(K_{i}=4-5 \mathrm{nM}\right)$. The structure of a close analog complexed with MCL-1 (PDB: 5VKC) indicates that it forms a typical hydrogen bond with Arg263, and binds to P2, P3 and P4 pockets with the naphthyl ring stretching deep into P2 pocket (Fig. 4e) [62]. A-1210477 disrupts the interaction between intracellular BIM and MCL-1 and promotes apoptosis in a mitochondria-dependent manner $[62,85]$.

\section{VU661013}

VU661013 is established after a series of structural optimizations, which has an effective and selective activity to MCL-1 $\left(K_{i}=97 \pm 30 \mathrm{pM}\right)$. It interferes with the binding stability of BIM and MCL-1 [63, 86-89]. The co-crystal structure MCL-1/VU661013 complex (PDB: $6 \mathrm{NE5})$ reveals that the dimethyl chlorophenyl ether of VU661013 inserts deep into P2 pocket, with the methyl group of the trimethyl pyrazole pointing towards P3 pocket (Fig. 4f) [90]. Notably, its indole headpiece makes a cation- $\pi$ interaction with Arg263, and positions the carboxylic acid to form a favorable hydrogen bond with Asn260 [90].

\section{MI-223}

Besides anti-apoptotic functions, MCL-1 is also involved in the regulation of non-apoptotic functions, including mitochondrial homeostasis, cell cycle regulation, DNA damage repair and autophagy [43]. MCL-1 interacts with the dimeric complex of $\mathrm{Ku}$ proteins through its $\mathrm{BH} 1$ and $\mathrm{BH} 3$ domains to inhibit $\mathrm{Ku}$ protein-mediated non-homologous end-joining and promote homologous recombination-mediated DNA repair [91]. Based on this mechanism, a new small molecule compound MI-223 
Table 2 MCL-1 targeted anti-tumor drugs in the preclinical stage

\begin{tabular}{|c|c|c|c|c|c|}
\hline Compound & & $\begin{array}{l}\text { Efficacy towards malignant } \\
\text { cells }\end{array}$ & In vitro potency & drug discovery method & References \\
\hline MIM1 & & $\begin{array}{l}\text { MCL-1 dependent leukemia } \\
\text { cells }\end{array}$ & $I C_{50}:<4.2 \mu \mathrm{M}$ & HTS (2013) & {$[81]$} \\
\hline UMI-59/77 & & BxPC-3 xenograft model & $K_{i}: 490 n M$ & HTS (2014) & {$[84]$} \\
\hline Complex 39 & & $\begin{array}{l}\mathrm{NCl}-\mathrm{H} 460 \text { cell line and } \\
\text { xenograft model }\end{array}$ & $\mathrm{IC}_{50}: 12-18 \mu \mathrm{M}$ & & [102] \\
\hline Complex 14 & & $\mathrm{NCl}-\mathrm{H} 460$ xenograft model & Ki: $1.4 \mathrm{nM}$ & & [101] \\
\hline Pyridoclax/Compound12 & & Ovarian cancer cell line & - & $(2014 / 2018)$ & {$[77,78]$} \\
\hline ML311/EU-5346 & & Active MCL-1 cell line & $\mathrm{IC}_{50}: 0.31 \mu \mathrm{M}$ & HTS (2013) & {$[82,83]$} \\
\hline A-1210477 & & MCL-1-dependent cell lines & $K_{i}: 4-5 \mathrm{nM}$ & HTS (2015) & {$[62]$} \\
\hline $\mathrm{BIMSAHB}_{\mathrm{A}}$ & NA & DLBCL cell lines & $\mathrm{EC}_{50}: 2-18 \mu \mathrm{M}$ & & [79] \\
\hline MS1 & $\begin{array}{l}\text { PREIWMTQGLRRLGDEIN- } \\
\text { AYYAR }\end{array}$ & MCL-1 dependent cell lines & $K_{d}: 1.9 \pm 1.0 \mathrm{nM}$ & & {$[80]$} \\
\hline VU661013 & & $\begin{array}{c}\text { AML, MM, triple negative } \\
\text { breast cancer cell lines }\end{array}$ & $K_{i}: 97 \pm 30 \mathrm{pM}$ & $\begin{array}{l}\text { Structure-based design } \\
\text { (2018) }\end{array}$ & {$[90,124]$} \\
\hline Wang.Compound 12 & & NCl-H345 cell line & $\mathrm{IC}_{50}: 2.2 \mu \mathrm{M}$ & $\begin{array}{l}\text { Fragment-based approach } \\
\text { (2016) }\end{array}$ & [107] \\
\hline Compound8 & & $\begin{array}{l}\text { A2780, MCF-7, SMMC-7721 } \\
\text { and DLD1 cell lines }\end{array}$ & $\mathrm{IC}_{50}: 38-47 \mu \mathrm{M}$ & Virtual screening (2017) & {$[108]$} \\
\hline Compound24 & & Lymphoma cell lines & $K_{i}: 100 \mathrm{nM}$ & $\begin{array}{l}\text { HTS and virtual screening } \\
(2020)\end{array}$ & [109] \\
\hline Compound M08 & & $\begin{array}{l}\text { Hematological and solid } \\
\text { cancer cell lines }\end{array}$ & $\mathrm{K}_{\mathrm{i}}: 0.53 \pm 0.07 \mu \mathrm{M}$ & $\begin{array}{l}\text { Structure-based virtual } \\
\text { screening (2020) }\end{array}$ & [110] \\
\hline
\end{tabular}


Table 2 (continued)

\begin{tabular}{|c|c|c|c|c|c|}
\hline Compound & & $\begin{array}{l}\text { Efficacy towards malignant } \\
\text { cells }\end{array}$ & In vitro potency & drug discovery method & References \\
\hline Compound5 & & $\begin{array}{l}\text { L-363, LP-1, NCI-H929 and } \\
\text { MOLP-8 }\end{array}$ & $\mathrm{IC}_{50}: 3.4 \mathrm{nM}$ & & [92] \\
\hline C3 & & HeLa, K562, NCl-H23 cell line & $I C_{50}: 0.78 \pm 0.12 \mu \mathrm{M}$ & (2019) & [105] \\
\hline $\mathrm{dMCL} 1-2$ & & MM cell line OPM2 & $K_{d}: 30 \mathrm{nM}$ & (2019) & {$[104]$} \\
\hline Ml-223 & & H1299 cell & $K_{d}: 193 \pm 4.3 \mathrm{nM}$ & Virtual screening (2018) & [91] \\
\hline APG-3526 & NA & MM cell line & $\mathrm{IC}_{50}: 7 \mathrm{nM}$ & $(2020)$ & [106] \\
\hline
\end{tabular}

$E C_{50}$ Half-maximal concentration of drug, $I C_{50}$ Concentration inhibitory to $50 \%$ of cells, $K_{i}$ Inhibition constant, $K_{d}$ Dissociation constant

was discovered, which directly binds to the BH1 domain of MCL-1 $\left(K_{i}=193 \pm 4.3 \mathrm{nM}\right)$, disrupts MCL-1 and $\mathrm{Ku}$ protein interactions.

\section{Covalent inhibitory}

Covalent inhibitors exert biological functions by interacting with target protein residues through covalent bonds. Therefore, they have the advantages of high selectivity, strong affinity, low effective drug concentration and low possibility of resistance. Akçay et al. [92] analyzed the crystal structure of MCL-1 and concluded that Lys234 was likely to be covalently modified. Subsequently, they used aryl boronic acid to covalently modify the noncatalytic lysine residues. In a panel of compounds, compound 5 had an $\mathrm{IC}_{50}$ of $3.4 \mathrm{nM}$, and compound 11 directly interfered with the MCL-1/BAK interaction in the cell. After mutation of the lysine 234 site, no covalent compounds were formed by mass spectrometry analysis, further verifying that Lys234 was covalently modified. Additionally, the efficacy of this reversible covalent inhibitor in vivo needs to be further refined.

\section{Natural products}

Some drugs extracted from natural products are characterized by high biological activity and low toxicity [93].
Gapil et al. extracted 26 carboxamides from natural fislatifolic acid, one of which exhibited submicromolar affinity for MCL-1 and BCL-2, and showed moderate cytotoxicity in lung and breast cancer cell lines [94]. Meiogynin A1 inhibited BCL-xL and MCL-1, and had no toxic effects on normal cells [95]. The modification of side chains gives these compounds better affinity and antitumor activity [96]. Cryptosphaerolide inhibited the interaction between MCL-1 and BAK and showed strong inhibitory activity against colon cancer cell line HCT-116 with an $\mathrm{IC}_{50}$ of $4.5 \mu \mathrm{M}$ [97]. Maritoclax selectively inhibits the proliferation of leukemic cells with high MCL-1 expression and significantly enhances the therapeutic effect of ABT-737 on various hematological malignancies $[98,99]$.

\section{Metal-based complexes}

Copper is essential element that participate in the reactions of various enzymes in the body, so copper-based complexes are promising anti-cancer drugs [100]. Lu et al. designed and synthesized a series of copper(II) complexes of 9-substituted $\beta$-carboline [101]. Complex 14 was able to selectively inhibit MCL-1 and disrupt MCL-1/BAX and MCL-1/BAK complexes in tumor cells, inducing BAX/BAK-dependent apoptosis in tumor cells. Structural model indicates that complex 39 can interact 
with Arg263 of MCL-1 while the long alkyl chain inserted into the P2 pocket of MCL-1 [102]. These findings have laid the foundation for the development of metal-based MCL-1 inhibitors.

\section{MCL-1 PROTACs}

Proteolysis-targeting chimeras (PROTACs) are a novel class of drug molecules designed to degrade proteins. They consist of three parts: an E3-binding ubiquitin ligase, a moiety that binds to the target protein, and a linker group that connects the two [103]. Recruitment of E3 ligase to the target protein can lead to proteasomal ubiquitination and subsequent degradation of the target protein. Structure-activity relationship (SAR) studies have yielded dMCL1-2 $(\mathrm{Kd}=30 \mathrm{nM})$ [104] and C3 $\left(\mathrm{IC}_{50}=0.78 \pm 0.12 \mu \mathrm{M}\right)$ [105]. Through the formation of a "target protein-PROTAC-E3 ligase" complex, the affinity between MCL-1 and the E3 ligase CRBN is effectively enhanced, which selectively degrades MCL-1 to obtain stronger tumor cell killing activity.

\section{Other compounds}

Ascentage Pharma has recently identified two lead compounds for MCL-1 inhibitors, APG-3526 and AS00491, using a protein-protein interaction platform [106]. In vitro and in vivo studies demonstrates that APG-3526 $\left(\mathrm{IC}_{50}=7 \mathrm{nM}\right)$ and AS00491 have high affinity for MCL-1 and anti-tumor proliferative capacity [106]. There are also many other preclinical MCL-1 inhibitors [102, 107110] (Table 2). These compounds aim to promote MCL1-dependent cancer cell apoptosis and exhibit differential activity.

\section{Targeting MCL-1 in different cancers}

Evasion of apoptosis through dysregulation of BCL-2 family is a significant hallmark of tumorigenesis and drug resistance. Different types of tumors determine the sensitivity to MCL-1 inhibitors by the expression of MCL-1. MCL-1 inhibitors can restart apoptosis when in combination with other therapies, allowing various cancer types to benefit from it. Here, we present the pathological and treatment role of MCL-1 in different kinds of cancers.

\section{Multiple myeloma}

Gain or amplification of chromosome 1q21 encoding MCL-1 and IL-6 receptor in patients with MM is associated with significantly shorter progression-free survival [111]. MCL-1 protein expression increased in newly diagnosed MM patients, with higher levels in relapsed patients [112]. Most MM cell lines are dependent on MCL-1 for survival, and targeting MCL-1 induces apoptosis in approximately 70\% of myeloma cell lines [113].
Cell-dependent analysis of 33 human MM cell lines showed a significant increase in MCL-1 dependence from $33 \%$ at diagnosis to $69 \%$ at relapse, suggesting that MCL-1 cell dependence favors relapse [114].

Targeting MCL-1 represents a novel and effective strategy for the treatment of MM. S63845 showed high efficacy and sensitivity in a panel of MM cell lines with $\mathrm{IC}_{50}<0.1 \mu \mathrm{M}$, and exhibited dose-dependent antitumor activity in MM xenograft mice. Moreover, S63845 may be effective in cases with refractory/relapsed MM or drug resistance, as its efficacy is not limited to patients carrying chromosomal translocations or mutations. 100 days after treatment of the AMO1 (MM cell line) model with $25 \mathrm{mg} / \mathrm{kg}$ dose of S63845, seven mice (eight in total) showed complete tumor regression [55].

AZD5991 directly binds to MCL-1 in MOLP-8 (MM cell line) cells and releases BAK from the MCL-1/BAK complex within $15 \mathrm{~min}$ at a concentration of $10 \mathrm{nM}$ [61]. After a single intravenous injection of $10 \mathrm{mg} / \mathrm{kg}, 30 \mathrm{mg} /$ $\mathrm{kg}$, and $100 \mathrm{mg} / \mathrm{kg}$ AZD5991, xenograft models of MM mice showed $52 \%, 93 \%$, and almost complete $100 \%$ tumor regression, respectively [61].

In MM xenograft models, oral administration of AMG-176 resulted in BAK activation, cleaved caspase 3 , and cleaved poly-ADP ribose polymerase (PARP) within $2 \mathrm{~h}$ [65]. Also in MM mice, oral administration of AMG-176 at a daily dose of $60 \mathrm{mg} / \mathrm{kg}$ or once-weekly dose of $100 \mathrm{mg} / \mathrm{kg}$ achieved $100 \%$ tumor growth inhibition and 97\% regression, respectively. The combination of AZD5991 or AMG-176 with venetoclax or proteasome inhibitors achieves a more potent antitumor killing effect than either single agent in MM [61, 65]. In MM xenografts models, AMG-397 administered orally once or twice weekly at 25 or $50 \mathrm{mg} / \mathrm{kg}$ exhibited significant tumor regression [66]. Of these, nine mice (ten in total) in the dose of $50 \mathrm{mg} / \mathrm{kg}$ had complete tumor regression at the end of the study [66].

\section{Leukemia}

AML usually exhibits heterogeneous expression of antiapoptotic proteins, especially MCL-1 [115]. Detection of BCL-2, BCL-xL and MCL-1 expression in hematopoietic progenitor cells and leukemic cells from AML patients revealed that MCL-1 transcripts were expressed at high levels in all samples tested [116]. MCL-1 is a key survival molecule required to promote the survival of $B$ progenitor cell populations during BCR-ABL transformation and the continued survival of BCR-ABL B-acute lymphoblastic leukemia cells [117]. MCL-1 overexpression has been identified in chemotherapy-relapsed AML and is a major factor in resistance to the dual BCL-2/BCL-XL inhibitor ABT-737 in AML cell lines [118]. MCL-1 and BCL-xL 
can make cells resistant to the BCL-2 inhibitor ABT-199 [119].

MCL-1 inhibition can be a rational therapeutic approach against AML. All eight AML cell lines were sensitive to $S 63845$ treatment with $\mathrm{IC}_{50}$ values of 4-233 nM [55]. AML xenograft model mice treated with $25 \mathrm{mg} / \mathrm{kg}$ dose of $\mathrm{S} 63845$ for 80 days resulted in complete remission in 6 out of 8 mice [55]. Compared to other BH3 mimics, such as ABT-199/A1331852 $\left(\mathrm{EC}_{50}<3 \mu \mathrm{M}\right)$, S63845 is more effective in killing primary AML cells and their derived cell lines $\left(\mathrm{EC}_{50}<150 \mathrm{nM}\right)$ and has the least toxicity to CD34+ progenitor cells [120].

AZD5991 induced apoptosis only in MCL-1-dependent cells. In AML mouse models, once weekly intravenous injection of $60 \mathrm{mg} / \mathrm{kg}$ AZD5991 reduced leukemic cells in both peripheral blood and bone marrow, while daily oral administration of $100 \mathrm{mg} / \mathrm{kg}$ venetoclax only reduced leukemic cells in peripheral blood [61]. For AML cells resistant to either single agent, AZD5991 combination with Venetoclax can overcame resistance without significant changes in body weight [61]. The synergistic effect of AZD5991 with penatinib or venetoclax results in a new clinical choice for patients with T315I (+) Ph + leukemia [121].

In the MOLM-13 luciferase labeled AML model, oral AMG 176 at a dose of $60 \mathrm{mg} / \mathrm{kg}$ twice weekly resulted in $69 \%$ tumor regression [65]. Treatment of MOLM-13 mice with AMG-176 $(30 \mathrm{mg} / \mathrm{kg})$ twice weekly or with venetoclax $(50 \mathrm{mg} / \mathrm{kg})$ daily both significantly reduced tumor load by $55 \%$ and $23 \%$, respectively. Synergistic use demonstrated $100 \%$ complete tumor suppression compared to monotherapy. Similar results were obtained in samples of patients with primary AML. In 9 of 13 samples, the combination of equimolar concentrations of AM-8621 and venetoclax significantly inhibited tumors compared to either drug alone [65]. Compared to DMSO, AMG176 caused a negligible number of normal hematopoietic cell deaths [122].

AMG-397 showed a strong sensitivity to AML cell lines. In the MOLM-13 orthotopic model of AML, twice-weekly dosing at $30 \mathrm{mg} / \mathrm{kg}$ achieved $99 \%$ tumor growth inhibition. The combination of oral AMG-397 at $10 \mathrm{mg} / \mathrm{kg}$ twice weekly and venetoclax at $50 \mathrm{mg} / \mathrm{kg}$ daily achieved 45\% regression [66].

A-1210477 overcomes the resistance of AML mouse models and cell lines to the BCL-2/BCL-XL inhibitor agent (ABT-737) [123]. VU661013-resistant AML cells were significantly more sensitive to venetoclax than their initial response and that cells resistant to venetoclax were more sensitive to MCL-1 inhibitors [124]. AML mice treated with VU661013 (75 mg/kg daily) for 3 weeks died of AML 42 days later. But with venetoclax effectively induced apoptosis [124].

\section{Non-Hodgkin lymphoma}

MCL-1 is highly expressed in malignant B cells and aggressive B-NHL [125]. MCL-1 transgenic mice develop B-cell lymphoma at high frequency [126]. MCL-1 is important for the survival of B lymphocyte progenitor cells in MYC-driven lymphomagenesis. Overexpression of MCL-1 greatly accelerates the development of lymphoma driven by the oncogene c-MYC. Although the loss of one MCL-1 allele does not significantly impair the survival of normal B lymphocyte-like cells, it almost completely abrogates the development of MYC-driven lymphomas [127]. MCL-1 knockdown triggers spontaneous apoptosis in several mantle cell lymphoma cell lines [128]. In two different mantle cell lymphoma cell lines, one normal cell line (JeKo-1) and one invasive cell line (MAVER-1), silencing MCL-1 induced a dose-dependent increase in the proportion of apoptotic cells [129].

In a human MCL-1 murine lymphoma transplant model, a single dose of $S 63845$ at $12.5 \mathrm{mg} / \mathrm{kg}$ or cyclophosphamide at $50 \mathrm{mg} / \mathrm{kg}$ in combination with $S 63845$ at $7.5 \mathrm{mg} / \mathrm{kg}$ inhibited tumor growth by $60 \%$ and almost $100 \%$, respectively [130]. S63845 combined with BCL-2/ BCL-xL inhibitors exhibited improved antitumor activity in B-cell acute lymphoblastic leukemia [131].

$\mathrm{BIM} \mathrm{SAHB}_{\mathrm{A}}$ can induce the apoptosis of diffuse large $B$ cell lymphoma (DLBCL) $\left(\mathrm{EC}_{50}=2-18 \mu \mathrm{M}\right)$, regardless of the expression of antiapoptotic proteins, and it is most effective among DLBCL with resistance to ABT737 and ABT-199 [79]. In BCL-2 $2^{\text {High }}$ NHL cell lines, both A-1210477 and CDK inhibitors downregulated MCL-1 expression and induced apoptosis in synergy with Venetoclax. In most BCL-2 ${ }^{\text {Low }}$ NHL cell lines, A-1210477 also exerted synergistic effects with navitoclax [132].

\section{Lung cancer}

Munkhbaatar et al. validated the high-frequency of MCL-1 in lung adenocarcinoma in multiple open databases [133]. MCL-1 overexpression is associated with poor survival in non-small cell lung cancer [134]. The PEST domain of MCL-1 interacts with AKT on the PH domain to activate AKT, which together promote lung cancer progression [135]. Lung cancer models with stable expression of BCL-xL and MCL-1 treated with radiotherapy induce negligible numbers of apoptotic cells [136].

S63845 induced cytotoxicity in lung adenocarcinoma cell lines is positively correlated with MCL-1 protein expression, which delays tumor progression and reduces tumor size in mouse [133]. MCL-1 inhibition can be used in combination with other therapeutic strategies to lower the apoptosis threshold [133]. MI-223 in combination with olaparib significantly inhibited lung tumor growth without hematological or histopathological toxicity [91]. 
Metal-based complex 14 and 39 significantly inhibited tumor growth in the NCI-H460 xenograft model [101].

\section{Breast cancer}

Amplification of MCL-1 is more frequent in clinical breast cancer datasets than BCL-2 and BCL-xL, and is associated with poor prognosis [137]. In vitro and in vivo experiments demonstrated the dependence of triple-negative breast cancers (TNBC) on MCL-1 [137]. HER2-positive breast cancer has significantly lower NOXA levels and mediates resistance to HER2 inhibitors through upregulation of MCL-1 [138].

In breast cancer with high expression of MCL-1, S63845 displayed synergistic activity with docetaxel in TNBC and with trastuzumab or lapatinib in HER2amplified breast cancer [139]. Combined inhibition of BCL-2 and BCL-xL with ABT-263 had limited efficacy on breast cancer owing to high expression of MCL-1, while A-1210477 or VU661013 in combination ABT-263 has a synergistic effect $[140,141]$. EU-5346 in combination with paclitaxel induced synergistic activity in both paclitaxel-sensitive and paclitaxel-resistant TNBC cells [142].

\section{Colorectal cancer}

MCL-1 expression is significantly increased in colorectal cancer and is associated with tumor stage, lymph node metastasis, and poor prognosis [143]. MCL-1 inhibitors synergize with standard therapies to exert antitumor activity in colorectal cancer. Decreased degradation of MCL-1 is involved in the E3 ubiquitin ligase FBW7 mutation-induced resistance to regorafenib in colorectal cancer patients [144]. The MCL-1 inhibitor S63845, AZD5991, AMG-176 restore sensitivity to regorafenib in FBW7 mutant colorectal cancer cells by restoring the apoptotic response [145]. In $\mathrm{BRAF}^{\mathrm{V} 600 \mathrm{E}}$-mutant colorectal cancer, mutant BRAF upregulates MCL-1 to confer apoptosis resistance [146]. MCL-1 inhibitor A-1210477 in combination with cobimetinib reverses colorectal cancer drug resistance and enhances cobimetinib-induced apoptosis [146].

\section{Melanoma}

Increased MCL-1 expression through oncogenic activation of BRAF was observed in cutaneous metastatic melanoma [147]. MCL-1 depletion significantly induced apoptosis in melanoma cells and resensitized mutant BRAF melanoma cells to anoikis compared with depletion of BCL-2 or BCL-xL [148]. Combined inhibition of MCL- 1 and BCL-xL by S63845/S64315 plus Navitoclax [149] or the combination of MCL-1 and BCL-2 by S63845/S64315 plus ABT-199 [150] synergistically induces extensive death in advanced/refractory melanoma cell lines both in vitro and in vivo. MIM1 promotes mitochondrial membrane rupture, glutathione depletion and cell cycle arrest, inducing melanoma cell death [151, 152].

\section{Hepatocellular carcinoma}

MCL-1 is a survival factor for hepatocellular carcinoma (HCC) [153]. MCL-1 expression was enhanced in HCC cell lines as well as in human HCC tissues. High expression of MCL-1 inhibits JQ1-triggered apoptosis in HCC cells [154]. MCL-1 knockdown or specific inhibitors of S63845 or A-1210477 significantly inhibited hepatocellular carcinoma spheroid cell formation and triggered apoptotic signals [153]. Targeting MCL-1 directly promoted apoptosis of hepatoma cells without affecting the growth of normal hepatocytes [155]. A combination of inhibitory CDK can overcome the resistance of hepatocellular carcinoma cells to sorafenib, and CDK-mediated inhibition of MCL-1 plays a key role in mediating this process [156].

\section{Other solid tumors}

The dependence of solid tumors on MCL-1 may be responsible for drug resistance. MCL-1 small molecule inhibitors, such as MIM1, UMI-77, and A-1210477, in combination with other standard therapies may be an effective strategy to restore the sensitivity of resistant cells, including head and neck squamous cell carcinoma [157], glioblastoma [158], cervical cancer [159], pancreatic cancer [84], ovarian cancer [160], and esophageal squamous cell carcinoma [161]. Thus, MCL-1 is a potential therapeutic target for restoring cell apoptosis in multidrug-resistant cancers. MCL-1 inhibitors in combination with existing radiotherapy/chemotherapy can overcome resistant/relapsed tumors, increasing the disease-free survival of cancer patients.

\section{Conclusions}

MCL-1 plays important roles in cancer development, and is associated with drug resistance of a variety of cancers. In recent years, significant progress has been made with MCL-1 inhibitors, and some drugs have entered clinical trials. In this review, we present a comprehensive summary of inhibitors that selectively target MCL-1, including small molecule inhibitors, peptide inhibitors, covalent inhibitors, natural products, metal-based complexes, and MCL-1 PROTACs. We analyze these inhibitors in terms of screening methods, chemical structures, binding modes and co-crystal structures. In addition, we discuss the use of MCL-1 selective inhibitors in different hematologic malignancies and solid tumors. In 2016, the FDA approved the BCL-2 selective inhibitor venetoclax for the treatment of chronic lymphocytic leukemia. As the clinical development of MCL-1 selective inhibitors 
progresses, MCL-1 selective inhibitors may become a new class of anti-cancer drugs that will bring clinical benefits to patients with a variety of hematologic malignancies and solid tumors.

\begin{abstract}
Abbreviations
AML: Acute myeloid leukemia; BH: BCL-2 homologous domains; CDK: Cyclindependent kinases; CLL: Chronic lymphocytic leukemia; DLBCL: Diffuse large B-cell lymphoma; HCC: Hepatocellular carcinoma; HTS: High-throughput screening; MCL-1: Myeloid leukemia 1; MDS: Myelodysplastic Syndrome; MM: Multiple Myeloma; MOMP: Mitochondrial outer membrane permeabilization NHL: Non-Hodgkin lymphoma; PARP: Poly-ADP ribose polymerase; PROTACs: Proteolysis-targeting chimeras; RS: Richter syndrome; SLL: Small lymphocytic lymphoma; TNBC: Triple-negative breast cancers.
\end{abstract}

\section{Acknowledgements}

Not applicable.

\section{Authors' contributions}

All authors were involved in the design of the review, and in writing the manuscript. All authors have read and approved the manuscript.

\section{Funding}

This work was supported by the National Natural Science Foundation of China (Grants 81570537 and 81974074 to Y.C.; Grant 31900880 to H.W.), China Postdoctoral Science Foundation (2019M652805), Science and Technology Planning Project of Hunan Province (2018TP1017).

\section{Availability of data and materials}

Not applicable.

\section{Declarations}

\section{Ethics approval and consent to participate}

Not applicable.

\section{Consent for publication}

Not applicable.

\section{Competing interests}

The authors declare that they have no competing interests.

\section{Author details}

${ }^{1}$ Department of Oncology, NHC Key Laboratory of Cancer Proteomics, Laboratory of Structural Biology, National Clinical Research Center for Geriatric Disorders, Xiangya Hospital, Central South University, Changsha 410008, Hunan, China. ${ }^{2}$ National Clinical Research Center for Geriatric Disorders, Xiangya Hospital, Central South University, Changsha 410008, Hunan, China.

Received: 18 January 2021 Accepted: 14 April 2021

Published online: 21 April 2021

\section{References}

1. Galluzzi L, Vitale I, Aaronson SA, Abrams JM, Adam D, Agostinis P, et al. Molecular mechanisms of cell death: recommendations of the Nomenclature Committee on Cell Death 2018. Cell Death Differ. 2018;25(3):486-541.

2. Green DR. The coming decade of cell death research: five riddles. Cell. 2019;177(5):1094-107.

3. Adams JM, Cory S. The BCL-2 arbiters of apoptosis and their growing role as cancer targets. Cell Death Differ. 2018;25(1):27-36.

4. Czabotar PE, Lessene G, Strasser A, Adams JM. Control of apoptosis by the BCL-2 protein family: implications for physiology and therapy. Nat Rev Mol Cell Biol. 2014;15(1):49-63.
5. Moldoveanu T, Follis A, Kriwacki R, Green D. Many players in BCL-2 family affairs. Trends Biochem Sci. 2014;39(3):101-11.

6. Fogarty L, Flemmer R, Geizer B, Licursi M, Karunanithy A, Opferman $J$, et al. $\mathrm{MCl}-1$ and $\mathrm{BCl}-\mathrm{xL}$ are essential for survival of the developing nervous system. Cell Death Differ. 2019;26(8):1501-15.

7. Opferman JT, Letai A, Beard C, Sorcinelli MD, Ong CC, Korsmeyer SJ, Opferman JT, et al. Development and maintenance of $B$ and $T$ lymphocytes requires antiapoptotic MCL-1. Nature. 2004:426(6967):671-6.

8. Wang X, Bathina M, Lynch J, Koss B, Calabrese C, Frase S, et al. Deletion of MCL-1 causes lethal cardiac failure and mitochondrial dysfunction. Genes Dev. 2013;27(12):1351-64.

9. Gores G, Kaufmann S. Selectively targeting Mcl-1 for the treatment of acute myelogenous leukemia and solid tumors. Genes Dev. 2012;26(4):305-11.

10. Hird AW, Tron AE. Recent advances in the development of MCl-1 inhibitors for cancer therapy. Pharmacol Ther. 2019;1 98(06):59-67.

11. Shahar N, Larisch S. Inhibiting the inhibitors: targeting anti-apoptotic proteins in cancer and therapy resistance. Drug Resist Update. 2020;52(09):100712.

12. Czabotar P, Lee E, van Delft M, Day C, Smith B, Huang D, et al. Structural insights into the degradation of $\mathrm{MCl}-1$ induced by $\mathrm{BH} 3$ domains. Proc Natl Acad Sci USA. 2007;104(15):6217-22.

13. Thomas LW, Lam C, Edwards SW. MCl-1; the molecular regulation of protein function. FEBS Lett. 2010;584(14):2981-9.

14. Morciano G, Giorgi C, Balestra D, Marchi S, Perrone D, Pinotti M, et al. $\mathrm{MCl}-1$ involvement in mitochondrial dynamics is associated with apoptotic cell death. Mol Biol Cell. 2016;27(1):20-34.

15. Bae J, Leo C, Hsu S, Hsueh A. MCL-1S, a splicing variant of the antiapoptotic BCL-2 family member MCL-1, encodes a proapoptotic protein possessing only the $\mathrm{BH} 3$ domain. J Biol Chem. 2000;275(33):25255-61.

16. Kim J, Bae J. MCL-1ES induces MCL-1L-dependent BAX-and BAK-independent mitochondrial apoptosis. PLoS ONE. 2013;8(11):e79626.

17. Kim J-H, Sim S-H, Ha H-J, Ko J-J, Lee K, Bae J. MCL-1ES, a novel variant of MCL-1, associates with MCL-1L and induces mitochondrial cell death. FEBS Lett. 2009;583(17):2758-64.

18. Véronèse $L$, Tournilhac $O$, Verrelle $P$, Davi F, Dighiero $G$, Chautard E, et al. Strong correlation between VEGF and MCL-1 mRNA expression levels in B-cell chronic lymphocytic leukemia. Leuk Res. 2009:33(12):1623-6.

19. Cherla R, Zhang Y, Ledbetter $L$, et al. Coxiella burnetii inhibits neutrophil apoptosis by exploiting survival pathways and antiapoptotic protein Mcl-1. Infect Immun. 2018;86(4):e00504-e517.

20. Choi B, Chun E, Kim SY, Kim M, Lee KY, Kim SJ. Notch-induced hIL-6 production facilitates the maintenance of self-renewal of hCD34+ cord blood cells through the activation of Jak-PI3K-STAT3 pathway. Am J Pathol. 2012;180(1):351-64.

21. Pan B, Wang D, Li L, Shang L, Xia F, Zhang F, et al. IL-22 Accelerates thymus regeneration via Stat3/Mcl-1 and decreases chronic graft-versushost disease in mice after allotransplants. Biol Blood Marrow Transplant. 2019;25(10):1911-9.

22. Shenoy AR, Kirschnek S, Häcker G. IL-15 regulates BCl-2 family members Bim and Mcl-1 through JAK/STAT and PI3K/AKT pathways in T cells. Eur J Immunol. 2014;44(8):2500-7.

23. Liu SM, Lin CH, Lu J, Lin IY, Tsai MS, Chen MH, et al. miR-596 modulates melanoma growth by regulating cell survival and death. J Investig Dermatol. 2018;138(4):911-21.

24. Abraham M, Klein S, Bulvik B, Wald H, Peled A. The CXCR4 inhibitor $\mathrm{BL}-8040$ induces the apoptosis of AML blasts by down-regulating ERK BCL-2, MCL-1 and cyclin-D1 via altered miR-15a/16-1 expression. Leukemia. 2017;31(11):2336-46

25. Klein S, Abraham M, Bulvik B, Dery E, Weiss ID, Barashi N, et al. CXCR4 promotes neuroblastoma growth and therapeutic resistance through miR-15a/16-1 mediated ERK and BCL2/cyclin D1 pathways. Cancer Res. 2018;78(6):1471-83.

26. Gao J, Li L, Wu M, Liu M, Xie X, Guo J, et al. MiR-26a inhibits proliferation and migration of breast cancer through repression of MCL-1. PLoS ONE. 2013:8(6):e65138

27. Shirjang S, Mansoori B, Asghari S, Duijf PHG, Mohammadi A, Gjerstorff $\mathrm{M}$, et al. MicroRNAs in cancer cell death pathways: apoptosis and necroptosis. Free Radic Biol Med. 2019;139(1):1-15. 
28. Schwickart M, Huang X, Lill JR, Liu J, Dixit VM. Deubiquitinase USP9X stabilizes MCL1 and promotes tumour cell survival. Nature. 2009;463(7277):103-7.

29. Zhang $S$, Zhang M, Jing $Y$, Yin $X, M a P$, Zhang Z, et al. Deubiquitinase USP13 dictates MCL1 stability and sensitivity to BH3 mimetic inhibitors. Nat Commun. 2018;9(1):215.

30. Maurer U, Charvet C, Wagman AS, Dejardin E, Green DR. Glycogen synthase kinase-3 regulates mitochondrial outer membrane permeabilization and apoptosis by destabilization of MCL-1. Mol Cell. 2006;21(6):749-60.

31. Nifoussi SK, Ratcliffe NR, Ornstein DL, Kasof G, Strack S, Craig RW. Inhibition of protein phosphatase 2A (PP2A) prevents $\mathrm{Mcl}-1$ protein dephosphorylation at the Thr-163/Ser-159 phosphodegron, dramatically reducing expression in Mcl-1-amplified lymphoma cells. J Biol Chem. 2014;289(32):21950-9.

32. Conage-Pough JE, Boise LH. Phosphorylation alters Bim-mediated Mcl-1 stabilization and priming. FEBS J. 2018;286(14):2626-40.

33. Nakajima W, Hicks MA, Tanaka N, Krystal GW, Harada H. Noxa determines localization and stability of MCL-1 and consequently ABT-737 sensitivity in small cell lung cancer. Cell Death Dis. 2014;5(2):e1052.

34. Pang X, Zhang J, Lopez H, Wang Y, Li W, O'Neill K, et al. The carboxylterminal tail of Noxa protein regulates the stability of Noxa and $\mathrm{Mcl}-1$. J Biol Chem. 2014;289(25):17802-11.

35. Fogha J, Marekha B, De Giorgi M, Voisin-Chiret AS, Rault S, Bureau R, et al. Towards understanding $\mathrm{Mcl}-1$ promiscuous and specific binding mode. J Chem Inf Model. 2017;57(11):2885-95.

36. Morsi RZ, Hage-Sleiman R, Kobeissy H, Dbaibo G. Noxa: role in cancer pathogenesis and treatment. Curr Cancer Drug Targets. 2018;18(10):914-28.

37. D'Aguanno S, Del Bufalo D. Inhibition of anti-apoptotic BCl-2 proteins in preclinical and clinical studies: current overview in cancer. Cells. 2020;9(5):1287.

38. Wei AH, Roberts AW, Spencer A, Rosenberg AS, Siegel D, Walter RB, et al. Targeting MCL-1 in hematologic malignancies: rationale and progress. Blood Rev. 2020;44:100672.

39. Moujalled D, Pomilio G, Ghiurau C, Ivey A, Salmon J, Rijal S, et al. Combining $\mathrm{BH} 3$-mimetics to target both $\mathrm{BCL}-2$ and $\mathrm{MCL} 1$ has potent activity in pre-clinical models of acute myeloid leukemia. Leukemia. 2019;33(4):905-17.

40. Yue S, Li Y, Chen X, Wang J, Li M, Chen Y, et al. FGFR-TKI resistance in cancer: current status and perspectives. J Hematol Oncol. 2021;14(1):23.

41. Jafarlou M, Shanehbandi D, Dehghan P, Mansoori B, Othman F, Baradaran B. Enhancement of chemosensitivity by simultaneously silencing of $\mathrm{Mcl}-1$ and Survivin genes using small interfering RNA in human myelomonocytic leukaemia. Artif Cells Nanomed Biotechnol. 2018:46(8):1792-8.

42. Xiang $W$, Yang C-Y, Bai L. MCL-1 inhibition in cancer treatment. Onco Targets Ther. 2018;11:7301-14

43. Senichkin V, Streletskaia A, Zhivotovsky B, Kopeina G. Molecular comprehension of $\mathrm{Mcl}-1$ : from gene structure to cancer therapy. Trends Cell Biol. 2019;29(7):549-62.

44. Quinn BA, Dash R, Azab B, Sarkar S, Das SK, Kumar S, et al. Targeting $\mathrm{Mcl}-1$ for the therapy of cancer. Expert Opin Investig Drugs. 2011;20(10):1397-411.

45. Ngoi N, Choong C, Lee J, Bellot G, Wong A, Goh B, et al. Targeting mitochondrial apoptosis to overcome treatment resistance in cancer. Cancers (Basel). 2020;12(3):574-603.

46. Oltersdorf T, Elmore S, Shoemaker A, Armstrong R, Augeri D, Belli B, et al. An inhibitor of $\mathrm{BCl}-2$ family proteins induces regression of solid tumours. Nature. 2005:435(7042):677-81.

47. Tse C, Shoemaker A, Adickes J, Anderson M, Chen J, Jin S, et al. ABT-263: a potent and orally bioavailable BCl-2 family inhibitor. Cancer Res. 2008;68(9):3421-8.

48. Souers A, Leverson J, Boghaert E, Ackler S, Catron N, Chen J, et al. ABT199, a potent and selective BCL-2 inhibitor, achieves antitumor activity while sparing platelets. Nat Med. 2013;19(2):202-8

49. Stewart ML, Fire E, Keating AE, Walensky LD. The MCL-1 BH3 helix is an exclusive MCL-1 inhibitor and apoptosis sensitizer. Nat Chem Biol. 2010;6(8):595-601.

50. Denis C, Sopková-deOliveiraSantos J, Bureau R, Voisin-Chiret AS. Hotspots of Mcl-1 protein. J Med Chem. 2020;63(3):928-43.
51. Rezende Miranda R, Fu Y, Chen X, Perino J, Cao P, Carpten J, et al. Development of a potent and specific FGFR4 inhibitor for the treatment of hepatocellular carcinoma. J Med Chem. 2020;63(20):11484-97.

52. Zhou M, Zheng H, Li Y, Huang H, Min X, Dai S, et al. Discovery of a novel AR/HDAC6 dual inhibitor for prostate cancer treatment. Aging. 2021;13(5):6982-98.

53. Leung C, Zhang J, Yang G, Liu H, Han Q, Ma D. Emerging screening approaches in the development of Nrf2-Keap1 protein-protein interaction inhibitors. Int J Mol Sci. 2019;20(18):4445.

54. Zhong H, Lee B, Boyle J, Wang W, Ma D, Hong Chan P, et al. Structure-based screening and optimization of cytisine derivatives as inhibitors of the menin-MLL interaction. Chem Commun (Camb). 2016:52(34):5788-91.

55. Kotschy A, Szlavik Z, Murray J, Davidson J, Maragno AL, Le ToumelinBraizat G, et al. The MCL1 inhibitor S63845 is tolerable and effective in diverse cancer models. Nature. 2016;538(7626):477-82.

56. Szlávik Z, Ondi L, Csékei M, Paczal A, Szabó Z, Radics G, et al. Structure-guided discovery of a selective Mcl-1 inhibitor with cellular activity. J Med Chem. 2019;62(15):6913-24.

57. Szlavik Z, Csekei M, Paczal A, Szabo ZB, Sipos S, Radics G, et al. Discovery of S64315, a potent and selective MCl-1 inhibitor. J Med Chem. 2020;63(22):13762-95.

58. Phase I Study of MIK665, a Mcl-1 Inhibitor, in Patients With Refractory or Relapsed Lymphoma or Multiple Myeloma. https://clinicaltrials. gov/ct2/show/NCT02992483. Accessed 20 September 2020.

59. Phase I Study of S64315 Administered Intravenously in Patients With Acute Myeloid Leukaemia or Myelodysplastic Syndrome. https://clini caltrials.gov/ct2/show/NCT02979366. Accessed 20 September 2020.

60. Phase I Dose Escalation Study of Intravenously Administered S64315 in Combination With Orally Administered Venetoclax in Patients With Acute Myeloid Leukaemia. https://clinicaltrials.gov/ct2/show/NCT03 672695. Accessed 20 September 2020.

61. Tron AE, Belmonte MA, Adam A, Aquila BM, Boise LH, Chiarparin E, et al. Discovery of Mcl-1-specific inhibitor AZD5991 and preclinical activity in multiple myeloma and acute myeloid leukemia. Nat Commun. 2018;9(1):5341.

62. Bruncko M, Wang L, Sheppard G, Phillips D, Tahir S, Xue J, et al. Structure-guided design of a series of MCL-1 inhibitors with high affinity and selectivity. J Med Chem. 2015;58(5):2180-94.

63. Friberg A, Vigil D, Zhao B, Daniels R, Burke J, Garcia-Barrantes P, et al. Discovery of potent myeloid cell leukemia 1 ( $\mathrm{MCl}-1)$ inhibitors using fragment-based methods and structure-based design. J Med Chem. 2013;56(1):15-30.

64. Study of AZD5991 in Relapsed or Refractory Haematologic Malignancies. https://clinicaltrials.gov/ct2/show/NCT03218683. Accessed 20 September 2020.

65. Caenepeel S, Brown SP, Belmontes B, Moody G, Keegan KS, Chui D, et al. AMG 176, a selective MCL1 inhibitor, is effective in hematologic cancer models alone and in combination with established therapies. Cancer Discov. 2018;8(12):1582-97.

66. Caenepeel S, Karen R, Belmontes B, Verlinsky A, Tan H, Yang Y, et al. Abstract 6218: discovery and preclinical evaluation of AMG 397, a potent, selective and orally bioavailable MCL1 inhibitor. Cancer Res. 2020;80(16 Supplement):6218.

67. Li K. Interdiction at a protein-protein interface: MCL-1 inhibitors for oncology. Bioorg Med Chem Lett. 2021;32:127717.

68. AMG 176 First in Human Trial in Subjects With Relapsed or Refractory Multiple Myeloma and Subjects With Relapsed or Refractory Acute Myeloid Leukemia. https://clinicaltrials.gov/ct2/show/NCT02675452. Accessed 20 September 2020.

69. A Study of Venetoclax and AMG 176 in Patients With Relapsed/ Refractory Hematologic Malignancies. https://clinicaltrials.gov/ct2/ show/NCT03797261. Accessed 20 September 2020

70. Safety, Tolerability, Pharmacokinetics and Efficacy of AMG 397 in Subjects with Multiple Myeloma, NHL, and AML. https://clinicaltrials. gov/ct2/show/NCT03465540. Accessed 20 September 2020.

71. A study of the safety and tolerability of ABBV-467 in adult participants with relapsed/refractory (R/R) multiple myeloma. https:/clini caltrials.gov/ct2/show/NCT04178902. Accessed 20 September 2020. 
72. A study of PRT1419 in patients with relapsed/refractory hematologic malignancies. https://clinicaltrials.gov/ct2/show/NCT04543305 Accessed 20 December 2020.

73. Guikema JE, Amiot M, Eldering E. Exploiting the pro-apoptotic function of NOXA as a therapeutic modality in cancer. Expert Opin Ther Targets. 2017;21(8):767-79.

74. Zhu Z-C, Liu J-W, Li K, Zheng J, Xiong Z-Q. KPNB1 inhibition disrupts proteostasis and triggers unfolded protein response-mediated apoptosis in glioblastoma cells. Oncogene. 2018;37(22):2936-52.

75. Ding X, Zhang Y, Huang T, Xu G, Peng C, Chen G, et al. Targeting sphingosine kinase 2 suppresses cell growth and synergizes with BCL2/BCL-XL inhibitors through NOXA-mediated MCL1 degradation in cholangiocarcinoma. Am J Cancer Res. 2019;9(3):546-61.

76. Medeiros HCD, Colturato-Kido C, Ferraz LS, Costa CA, Moraes VWR, Paredes-Gamero EJ, et al. AMPK activation induced by promethazine increases NOXA expression and Beclin-1 phosphorylation and drives autophagy-associated apoptosis in chronic myeloid leukemia. Chem Biol Interact. 2020;315:108888.

77. Hedir S, De Giorgi M, Fogha J, De Pascale M, Weiswald L-B, Brotin E, et al. Structure-guided design of pyridoclax derivatives based on Noxa/Mcl-1 interaction mode. Eur J Med Chem. 2018;159:357-80.

78. Gloaguen C, Voisin-Chiret AS, Sopkova-de Oliveira Santos J, Fogha J, Gautier F, De Giorgi M, et al. First evidence that oligopyridines, a-helix foldamers, inhibit Mcl-1 and sensitize ovarian carcinoma cells to BclXL-targeting strategies. J Med Chem. 2015;58(4):1644-68.

79. Hadji A, Schmitt GK, Schnorenberg MR, Roach L, Hickey CM, Leak LB, et al. Preferential targeting of MCL-1 by a hydrocarbon-stapled BIM BH3 peptide. Oncotarget. 2019;10(58):6219-33.

80. Foight G, Ryan J, Gullá S, Letai A, Keating A. Designed BH3 peptides with high affinity and specificity for targeting $\mathrm{MCl}-1$ in cells. ACS Chem Biol. 2014;9(9):1962-8.

81. Cohen Nicole A, Stewart Michelle L, Gavathiotis E, Tepper Jared L, Bruekner Susanne R, Koss B, et al. A Competitive stapled peptide screen identifies a selective small molecule that overcomes MCL1-dependent leukemia cell survival. Chem Biol. 2012;19(9):1175-86.

82. Bannister T, Koenig M, He Y, Mishra J, Spicer T, Minond D, et al., ML311: a small molecule that potently and selectively disrupts the protein-protein interaction of $\mathrm{Mcl}-1$ and Bim: a probe for studying lymphoid tumorigenesis. In Probe reports from the NIH molecular libraries program, National Center for Biotechnology Information (US): Bethesda (MD), 2010.

83. Richard DJ, Lena R, Bannister T, Blake N, Pierceall WE, Carlson NE, et al. Hydroxyquinoline-derived compounds and analoguing of selective Mcl-1 inhibitors using a functional biomarker. Bioorg Med Chem. 2013;21(21):6642-9.

84. Abulwerdi F, Liao C, Liu M, Azmi AS, Aboukameel A, Mady ASA, et al. A novel small-molecule inhibitor of $\mathrm{Mcl}-1$ blocks pancreatic cancer growth in vitro and in vivo. Mol Cancer Ther. 2014;13(3):565-75.

85. Leverson JD, Zhang H, Chen J, Tahir SK, Phillips DC, Xue J, et al. Potent and selective small-molecule MCL-1 inhibitors demonstrate ontarget cancer cell killing activity as single agents and in combination with ABT-263 (navitoclax). Cell Death Dis. 2015;6(1):e1590.

86. Burke J, Bian Z, Shaw S, Zhao B, Goodwin C, Belmar J, et al. Discovery of tricyclic indoles that potently inhibit Mcl-1 using fragment-based methods and structure-based design. J Med Chem. 2015;58(9):3794-805

87. Pelz N, Bian Z, Zhao B, Shaw S, Tarr J, Belmar J, et al. Discovery of 2-Indole-acylsulfonamide myeloid cell leukemia 1 (Mcl-1) inhibitors using fragment-based methods. J Med Chem. 2016;59(5):2054-66.

88. Shaw S, Bian Z, Zhao B, Tarr J, Veerasamy N, Jeon K, et al. Optimization of potent and selective tricyclic indole diazepinone myeloid cell leukemia-1 inhibitors using structure-based design. J Med Chem. 2018;61(6):2410-21.

89. Lee T, Bian Z, Zhao B, Hogdal L, Sensintaffar J, Goodwin C, et al. Discovery and biological characterization of potent myeloid cell leukemia-1 inhibitors. FEBS Lett. 2017:591(1):240-51.

90. Lee T, Christov PP, Shaw S, Tarr JC, Zhao B, Veerasamy N, et al. Discovery of potent myeloid cell leukemia-1 (Mcl-1) inhibitors that demonstrate in vivo activity in mouse xenograft models of human cancer. J Med Chem. 2019;62(8):3971-88.
91. Chen G, Magis A, Xu K, Park D, Yu D, Owonikoko T, et al. Targeting Mcl-1 enhances DNA replication stress sensitivity to cancer therapy. J Clin Investig. 2018;128(1):500-16.

92. Akçay G, Belmonte M, Aquila B, Chuaqui C, Hird A, Lamb M, et al. Inhibition of $\mathrm{MCl}-1$ through covalent modification of a noncatalytic lysine side chain. Nat Chem Biol. 2016;12(11):931-6.

93. Tan W, Lu J, Huang M, Li Y, Chen M, Wu G, et al. Anti-cancer natural products isolated from Chinese medicinal herbs. Chin Med. 2011;6(1):27.

94. Gapil Tiamas S, Daressy F, Abou Samra A, Bignon J, Steinmetz V, Litaudon $\mathrm{M}$, et al. Pro-apoptotic carboxamide analogues of natural fislatifolic acid targeting $\mathrm{MCl}-1$ and $\mathrm{BCl}-2$. Bioorg Med Chem Lett. 2020;30(7):127003.

95. Litaudon M, Bousserouel H, Awang K, Nosjean O, Martin M, Dau M, et al. A dimeric sesquiterpenoid from a Malaysian Meiogyne as a new inhibitor of $\mathrm{BCl}-\mathrm{xL} / \mathrm{BakBH} 3$ domain peptide interaction. J Nat Prod. 2009;72(3):480-3.

96. Abou Samra A, Robert A, Gov C, Favre L, Eloy L, Jacquet E, et al. Dual inhibitors of the pro-survival proteins $\mathrm{BCl}-2$ and $\mathrm{MCl}-1$ derived from natural compound meiogynin A. Eur J Med Chem. 2018;148:26-38.

97. Oh H, Jensen P, Murphy B, Fiorilla C, Sullivan J, Ramsey T, et al. Cryptosphaerolide, a cytotoxic $\mathrm{Mcl}-1$ inhibitor from a marinederived ascomycete related to the genus Cryptosphaeria. J Nat Prod. 2010;73(5):998-1001.

98. Haste N, Hughes C, Tran D, Fenical W, Jensen P, Nizet V, et al. Pharmacological properties of the marine natural product marinopyrrole $A$ against methicillin-resistant Staphylococcus aureus. Antimicrob Agents Chemother. 2011;55(7):3305-12.

99. Doi K, Li R, Sung SS, Wu H, Liu Y, Manieri W, et al. Discovery of marinopyrrole A (maritoclax) as a selective $\mathrm{Mcl}-1$ antagonist that overcomes ABT-737 resistance by binding to and targeting $\mathrm{Mcl}-1$ for proteasomal degradation. J Biol Chem. 2012;287(13):10224-35.

100. Molinaro C, Martoriati A, Pelinski L, Cailliau K. Copper complexes as anticancer agents targeting topoisomerases I and II. Cancers (Basel). 2020:12(10):2863.

101. Lu X, Liu Y, Orvig C, Liang H, Chen Z. Discovery of a copper-based Mcl-1 inhibitor as an effective antitumor agent. J Med Chem. 2020;63(17):9154-67.

102. Lu X, Liu Y, Orvig C, Liang H, Chen Z. Discovery of $\beta$-carboline copper(II) complexes as $\mathrm{Mcl}-1$ inhibitor and in vitro and in vivo activity in cancer models. Eur J Med Chem. 2019;181:111567.

103. Schapira M, Calabrese M, Bullock A, Crews C. Targeted protein degradation: expanding the toolbox. Nat Rev Drug Discov. 2019;18(12):949-63.

104. Papatzimas J, Gorobets E, Maity R, Muniyat M, MacCallum J, Neri P, et al. From inhibition to degradation: targeting the antiapoptotic protein myeloid cell leukemia 1 (MCL1). J Med Chem. 2019;62(11):5522-40.

105. Wang Z, He N, Guo Z, Niu C, Song T, Guo Y, et al. Proteolysis targeting chimeras for the selective degradation of $\mathrm{Mcl}-1 / \mathrm{BCl}-2$ derived from nonselective target binding ligands. J Med Chem. 2019;62(17):8152-63.

106. Chen J, Wu C, Jiao L, Zhao L, Zhou Y, Li D, et al. Abstract 73: development of APG-3526 as a novel and highly efficacious MCL-1 inhibitor. Cancer Res. 2020;80(16 Supplement):73.

107. Wang Z, Xu W, Song T, Guo Z, Liu L, Fan Y, et al. Fragment-based design, synthesis, and biological evaluation of 1-substitutedindole-2-carboxylic acids as selective Mcl-1 inhibitors. Arch Pharm. 2017;350(1):e1600251

108. Liu J, Tian Z, Zhou N, Liu X, Liao C, Lei B, et al. Targeting the apoptotic Mcl-1-PUMA interface with a dual-acting compound. Oncotarget. 2017;8(33):54236-42.

109. Kump K, Miao L, Mady A, Ansari N, Shrestha U, Yang Y, et al. Discovery and characterization of 2,5-substituted benzoic acid dual inhibitors of the anti-apoptotic $\mathrm{Mcl}-1$ and Bfl-1 proteins. J Med Chem. 2020;63(5):2489-510.

110. Du J, Liu L, Liu B, Yang J, Hou X, Yu J, et al. Structure-based virtual screening, biological evaluation and biophysical study of novel Mcl-1 inhibitors. Future Med Chem. 2020:12(14):1293-304.

111. Shah V, Sherborne AL, Walker BA, Johnson DC, Boyle EM, Ellis S, et al. Prediction of outcome in newly diagnosed myeloma: a metaanalysis of the molecular profiles of 1905 trial patients. Leukemia. 2018;32(1):102-10. 
112. Wuillème-Toumi S, Robillard N, Gomez P, Moreau P, Le Gouill S, AvetLoiseau $\mathrm{H}$, et al. Mcl-1 is overexpressed in multiple myeloma and associated with relapse and shorter survival. Leukemia. 2005;19(7):1248-52.

113. Gong J, Khong T, Segal D, Yao Y, Riffkin C, Garnier J, et al. Hierarchy for targeting prosurvival BCL2 family proteins in multiple myeloma: pivotal role of MCL1. Blood. 2016;128(14):1834-44.

114. Gomez-Bougie P, Maiga S, Tessoulin B, Bourcier J, Bonnet A, Rodriguez $\mathrm{M}$, et al. $\mathrm{BH} 3$-mimetic toolkit guides the respective use of BCL2 and MCL1 BH3-mimetics in myeloma treatment. Blood. 2018;132(25):2656-69.

115. Pan R, Hogdal L, Benito J, Bucci D, Han L, Borthakur G, et al. Selective $B C L-2$ inhibition by ABT-199 causes on-target cell death in acute myeloid leukemia. Cancer Discov. 2014;4(3):362-75.

116. Xiang Z, Luo H, Payton J, Cain J, Ley T, Opferman J, et al. MCL-1 haploinsufficiency protects mice from Myc-induced acute myeloid leukemia. J Clin Invest. 2010;120(6):2109-18.

117. Koss B, Morrison J, Perciavalle R, Singh H, Rehg J, Williams R, et al. Requirement for antiapoptotic MCL-1 in the survival of BCR-ABL B-lineage acute lymphoblastic leukemia. Blood. 2013;122(9):1587-98.

118. Konopleva M, Contractor R, Tsao T, Samudio I, Ruvolo P, Kitada S, et al. Mechanisms of apoptosis sensitivity and resistance to the $\mathrm{BH} 3$ mimetic ABT-737 in acute myeloid leukemia. Cancer Cell. 2006;10(5):375-88.

119. Wang $\mathrm{Q}$, Wan J, Zhang W, Hao S. MCL-1 or BCL-XL-dependent resistance to the BCL-2 antagonist (ABT-199) can be overcome by specific inhibitor as single agents and in combination with ABT-199 in acute myeloid leukemia cells. Leuk Lymphoma. 2019;60(9):2170-80.

120. Ewald L, Dittmann J, Vogler M, Fulda S. Side-by-side comparison of BH3-mimetics identifies MCL-1 as a key therapeutic target in AML. Cell Death Dis. 2019;10(12):917.

121. Inoue $C$, Sobue $S$, Kawamoto $Y$, Nishizawa $Y$, Ichihara $M$, Abe A, et al. Involvement of MCL1, c-myc, and cyclin D2 protein degradation in ponatinib-induced cytotoxicity against T315I(+) Ph+leukemia cells. Biochem Biophys Res Commun. 2020;525(4):1074-80.

122. Yi X, Sarkar A, Kismali G, Aslan B, Ayres M, Iles LR, et al. AMG-176, an Mcl-1 antagonist, shows preclinical efficacy in chronic lymphocytic leukemia. Clin Cancer Res. 2020;26(14):3856-67.

123. Wang Q, Hao S. A-1210477, a selective MCL-1 inhibitor, overcomes ABT737 resistance in AML. Oncol Lett. 2019;18(5):5481-9.

124. Ramsey HE, Fischer MA, Lee T, Gorska AE, Arrate MP, Fuller L, et al. A novel MCL1 inhibitor combined with venetoclax rescues venetoclax-resistant acute myelogenous leukemia. Cancer Discov. 2018:8(12):1566-81.

125. Klanova M, Klener P. BCL-2 Proteins in Pathogenesis and Therapy of B-Cell Non-Hodgkin Lymphomas. Cancers (Basel). 2020;12(4):938.

126. Wenzel SS, Grau M, Mavis C, Hailfinger S, Wolf A, Madle H, et al. MCL1 is deregulated in subgroups of diffuse large B-cell lymphoma. Leukemia. 2013;27(6):1381-90

127. Grabow S, Delbridge A, Aubrey B, Vandenberg C, Strasser A. Loss of a single $\mathrm{MCl}-1$ allele inhibits MYC-driven lymphomagenesis by sensitizing Pro-B cells to apoptosis. Cell Rep. 2016;14(10):2337-47.

128. Dengler M, Teh C, Thijssen $R$, Gangoda L, Lan P, Herold M, et al. Potent efficacy of MCL-1 inhibitor-based therapies in preclinical models of mantle cell lymphoma. Oncogene. 2020;39(9):2009-23.

129. Knapp C, He J, Lister J, Whitehead K. Lipidoid nanoparticle mediated silencing of $\mathrm{Mcl}-1$ induces apoptosis in mantle cell lymphoma. Exp Biol Med (Maywood). 2016;241(9):1007-13.

130. Brennan MS, Chang C, Tai L, Lessene G, Strasser A, Dewson G, et al. Humanized $\mathrm{Mcl}-1$ mice enable accurate preclinical evaluation of $\mathrm{MCL}-1$ inhibitors destined for clinical use. Blood. 2018;132(15):1573-83.

131. Moujalled D, Hanna D, Hediyeh-Zadeh S, Pomilio G, Brown L, Litalien $\checkmark$, et al. Cotargeting BCL-2 and MCL-1 in high-risk B-ALL. Blood Adv. 2020;4(12):2762-7.

132. Phillips D, Xiao Y, Lam L, Litvinovich E, Roberts-Rapp L, Souers A, et al. Loss in MCL-1 function sensitizes non-Hodgkin's lymphoma cell lines to the BCL-2-selective inhibitor venetoclax (ABT-199). Blood Cancer J. 2015;5(11):e368

133. Munkhbaatar E, Dietzen M, Agrawal D, Anton M, Jesinghaus M, Boxberg $M$, et al. MCL-1 gains occur with high frequency in lung adenocarcinoma and can be targeted therapeutically. Nat Commun. 2020;11(1):4527
134. Nakano T, Go T, Nakashima N, Liu D, Yokomise H. Overexpression of antiapoptotic MCL-1 predicts worse overall survival of patients with non-small cell lung cancer. Anticancer Res. 2020;40(2):1007-14.

135. Chen G, Park D, Magis A, Behera M, Ramalingam S, Owonikoko T, et al. $\mathrm{Mcl}-1$ interacts with Akt to promote lung cancer progression. Cancer Res. 2019;79(24):6126-38.

136. Wieczorek S, Breitenbuecher F, Soni A, Paul-Konietzko K, Ziegler S, Sak $A$, et al. Deregulated BCL-2 family proteins impact on repair of DNA double-strand breaks and are targets to overcome radioresistance in lung cancer. J Cancer Res Clin Oncol. 2017;143(9):1733-44.

137. Campbell K, Dhayade S, Ferrari N, Sims A, Johnson E, Mason S, et al. $\mathrm{MCL}-1$ is a prognostic indicator and drug target in breast cancer. Cell Death Dis. 2018;9(2):19.

138. Floros K, Lochmann T, Hu B, Monterrubio C, Hughes M, Wells J, et al. miR-4728Coamplification of protects-amplified breast cancers from targeted therapy. Proc Natl Acad Sci USA. 2018;115(11):E2594-603.

139. Merino D, Whittle JR, Vaillant F, Serrano A, Gong JN, Giner G, et al. Synergistic action of the MCL-1 inhibitor 563845 with current therapies in preclinical models of triple-negative and HER2-amplified breast cancer. Sci Transl Med. 2017:9(401):eaam7049.

140. Xiao Y, Nimmer P, Sheppard G, Bruncko M, Hessler P, Lu X, et al. MCL-1 Is a key determinant of breast cancer cell survival: validation of MCL-1 dependency utilizing a highly selective small molecule inhibitor. Mol Cancer Ther. 2015;14(8):1837-47.

141. Williams M, Elion D, Rahman B, Hicks D, Sanchez V, Cook R. Therapeutic inhibition of $\mathrm{Mcl}-1$ blocks cell survival in estrogen receptor-positive breast cancers. Oncotarget. 2019:10(52):5389-402.

142. Vallet S, Fan F, Malvestiti S, Pecherstorfer M, Sattler M, Schneeweiss $\mathrm{A}$, et al. Rationally derived drug combinations with the novel Mcl-1 inhibitor EU-5346 in breast cancer. Breast Cancer Res Treat. 2019:173(3):585-96.

143. Lee W, Park Y, Kim N, Oh H, Son D, Kim M, et al. Myeloid cell leukemia-1 is associated with tumor progression by inhibiting apoptosis and enhancing angiogenesis in colorectal cancer. Am J Cancer Res. 2015;5(1):101-13.

144. Tong J, Tan S, Zou F, Yu J, Zhang L. FBW7 mutations mediate resistance of colorectal cancer to targeted therapies by blocking Mcl-1 degradation. Oncogene. 2017:36(6):787-96.

145. Song X, Shen L, Tong J, Kuang C, Zeng S, Schoen R, et al. Mcl-1 inhibition overcomes intrinsic and acquired regorafenib resistance in colorectal cancer. Theranostics. 2020;10(18):8098-110.

146. Kawakami H, Huang S, Pal K, Dutta S, Mukhopadhyay D, Sinicrope F. Mutant BRAF upregulates MCL-1 to confer apoptosis resistance that is reversed by $\mathrm{MCL}-1$ antagonism and cobimetinib in colorectal cancer. Mol Cancer Ther. 2016;15(12):3015-27.

147. McKee C, Hill D, Redfern C, Armstrong J, Lovat P. Oncogenic BRAF signalling increases $\mathrm{Mcl}-1$ expression in cutaneous metastatic melanoma. Exp Dermatol. 2013;22(11):767-9.

148. Boisvert-Adamo K, Longmate W, Abel EV, Aplin AE. Mcl-1 is required for melanoma cell resistance to anoikis. Mol Cancer Res. 2009;7(4):549-56.

149. Mukherjee N, Skees J, Todd K, West D, Lambert K, Robinson W, et al. MCL1 inhibitors S63845/MIK665 plus Navitoclax synergistically kill difficult-to-treat melanoma cells. Cell Death Dis. 2020:11(6):443.

150. Mukherjee N, Amato C, Skees J, Todd K, Lambert K, Robinson W, et al. Simultaneously inhibiting BCL2 and MCL1 is a therapeutic option for patients with advanced melanoma. Cancers (Basel). 2020;12(8):2182.

151. Respondek M, Beberok A, Rzepka Z, Rok J, Wrześniok D. MIM1 induces COLO829 melanoma cell death through mitochondrial membrane breakdown, GSH depletion, and DNA damage. Fundam Clin Pharmacol. 2020;34(1):20-31.

152. Respondek M, Beberok A, Rzepka Z, Rok J, Wrześniok D. Mcl-1 inhibitor induces cells death in BRAF-mutant amelanotic melanoma trough GSH depletion, DNA damage and cell cycle changes. Pathol Oncol Res. 2020;26(3):1465-74

153. Zhang H, Li G, Chen G, Zhang Y, Pan J, Tang H, et al. Targeting Mcl-1 inhibits survival and self-renewal of hepatocellular cancer stem-like cells. Clin Res Hepatol Gastroenterol. 2019;43(3):292-300.

154. Zhang H, Li G, Zhang Y, Guo W, Zhang J, Li J, et al. Upregulation of MCl-1 inhibits JQ1-triggered anticancer activity in hepatocellular carcinoma cells. Biochem Biophys Res Commun. 2018;495(4):2456-61. 
155. Sieghart W, Losert D, Strommer S, Cejka D, Schmid K, Rasoul-Rockenschaub S, et al. Mcl-1 overexpression in hepatocellular carcinoma: a potential target for antisense therapy. J Hepatol. 2006;44(1):151-7.

156. Hsu C, Lin LI, Cheng YC, Feng ZR, Shao YY, Cheng AL, et al. Cyclin E1 inhibition can overcome sorafenib resistance in hepatocellular carcinoma cells through Mcl-1 suppression. Clin Cancer Res. 2016;22(10):2555-64.

157. OwT, Thomas C, Fulcher C, Chen J, López A, Reyna D, et al. Apoptosis signaling molecules as treatment targets in head and neck squamous cell carcinoma. Laryngoscope. 2020;130(11):2643-9.

158. Chen C, Zhu S, Zhang X, Zhou T, Gu J, Xu Y, et al. Targeting the synthetic vulnerability of PTEN-deficient glioblastoma cells with MCL1 inhibitors. Mol Cancer Ther. 2020;19(10):2001-11.

159. Lian B, Yek A, Shuvas H, Abdul Rahman S, Muniandy K, MohanaKumaran N. Synergistic anti-proliferative effects of combination of
ABT-263 and MCL-1 selective inhibitor A-1210477 on cervical cancer cell lines. BMC Res Notes. 2018;11(1):197.

160. Habata S, Iwasaki M, Sugio A, Suzuki M, Tamate M, Satohisa S, et al. BAG3-mediated Mcl-1 stabilization contributes to drug resistance via interaction with USP9X in ovarian cancer. Int J Oncol. 2016;49(1):402-10.

161. Lin J, Fu D, Dai Y, Lin J, Xu T. MCl-1 inhibitor suppresses tumor growth of esophageal squamous cell carcinoma in a mouse model. Oncotarget. 2017;8(70):114457-62.

\section{Publisher's Note}

Springer Nature remains neutral with regard to jurisdictional claims in published maps and institutional affiliations.
Ready to submit your research? Choose BMC and benefit from:

- fast, convenient online submission

- thorough peer review by experienced researchers in your field

- rapid publication on acceptance

- support for research data, including large and complex data types

- gold Open Access which fosters wider collaboration and increased citations

- maximum visibility for your research: over $100 \mathrm{M}$ website views per year

At BMC, research is always in progress.

Learn more biomedcentral.com/submissions 